\title{
Morphological variation in Miniopterus pusillus and M. australis (sensu Hill 1992) in southeastern Asia, New Guinea and Australia
}

\author{
D.J. Kitchener' and A. Suyanto ${ }^{2}$ \\ ' Western Australian Museum, Francis Street, Perth, Western Australia 6000, Australia \\ ${ }^{2}$ Balitbang Zoologi, LIPI, Jalan Ir. H. Juanda 9, Bogor, Indonesia 16002
}

\begin{abstract}
The morphology of 366 specimens of small (forearm $<45 \mathrm{~mm}$; cranial mastoid width $<7.9 \mathrm{~mm}$ ) Miniopterus from Indonesia, Philippines, New Guinea and Australia was examined, with the assistance of univariate and multivariate statistical analyses.

Four species (M. pusillus, M. australis, M. paululus and $M$. shortridgei) are recognised. Each of these species differentiates into recognisable forms, mostly named, but a new subspecies is described for $M$. paululus from Selaru island. Indeterminate subspecies are recognised for $M$. pusillus from Alor, Roti and Seram islands; M. australis from Kai island; and $M$. shortridgei from islands in the Outer Banda Arc and Wetar island.

There was no marked sexual dimorphism among populations of these species, except in cranial height, where males were larger.

These are the first records of $M$. pusillus on Lombok, Sumbawa, Alor and Roti islands; and of M. shortridgei on Madura, Lombok, Sumbawa, Alor, Roti, Semau, Savu, Wetar and Selaru islands.
\end{abstract}

\section{INTRODUCTION}

According to Hill in Corbet and Hill (1992), the small species of Miniopterus in eastern Indonesia, Philippines, New Guinea and Australia which have a forearm length of less than $45 \mathrm{~mm}$ and a mastoid width less than $7.9 \mathrm{~mm}$, comprise only the two species: $M$. australis Tomes, 1858 and $M$. pusillus Dobson, 1876. Hill (1983) tabulated several cranial, dentary and external body measurements of a number of populations of $M$. australis and $M$. pusillus. He stated that these species were sympatric over much of their distributional overlap. Where they occur together they can be distinguished by "the slightly greater external size of pusillus". However, according to Hill (1983) the literature contains many examples of these two species being misidentified.

A number of taxa have been recognised among the small species of Miniopterus in or adjacent to Indonesia, Philippines, New Guinea and Australia. These are listed below, along with their type localities:

Miniopterus australis australis Tomes, 1858 - Loyalty islands (but see Hill 1983: 171-173)

M. australis shortridgei Laurie and Hill, 1957 Kalipoetjang, Tji - Tandoei R., south Java

M. a. minor Laurie and Hill, 1954 - Kalipoetjang, Tji - Tandoei R., south Java

M. tibialis (Tomes, 1858) - Ambon island, Maluku Tenggara
M. paululus Hollister, 1913 - Guimaras island, Philippines

M. macrocneme Revilliod, 1914 - New Caledonia and Loyalty islands

M. witkampi Sody, 1930 - Lobang Ipoe, Koetai, eastern Kalimantan, Borneo

M. pusillus Dobson, 1876 - Nicobar island

M. solomonensis Maeda, 1982 - Malaita and San Christobal, Solomon islands

There has been considerable confusion as to the taxonomic relationships among these taxa. For example Tate (1941) stated that "witkampi is a synonym of pusillus" and "macrocneme from Loyalty islands is apparently synonymous with australis". However, Petersen (1981b) and Hill (1983) associated macrocneme with pusillus, while Maeda (1982) associated macrocneme with the Miniopterus fuscus group of species.

Hill (1983) and Hill in Corbet and Hill (1992) considered tibialis, witkampi, paululus, shortridgei and solomonensis as subspecies of $M$. australis.

Tate (1941) considered australis synonymous with paululus; an opinion supported by Sanborn (1952) and considered possible by Hill (1983). Sanborn (1952) also thought it likely that tibialis was a synonym of australis. Petersen (1981a) disagreed somewhat and suggested that paululus and shortridgei were distinct from australis. Maeda (1982) and Koopman (1982) considered paululus a species; and the former 


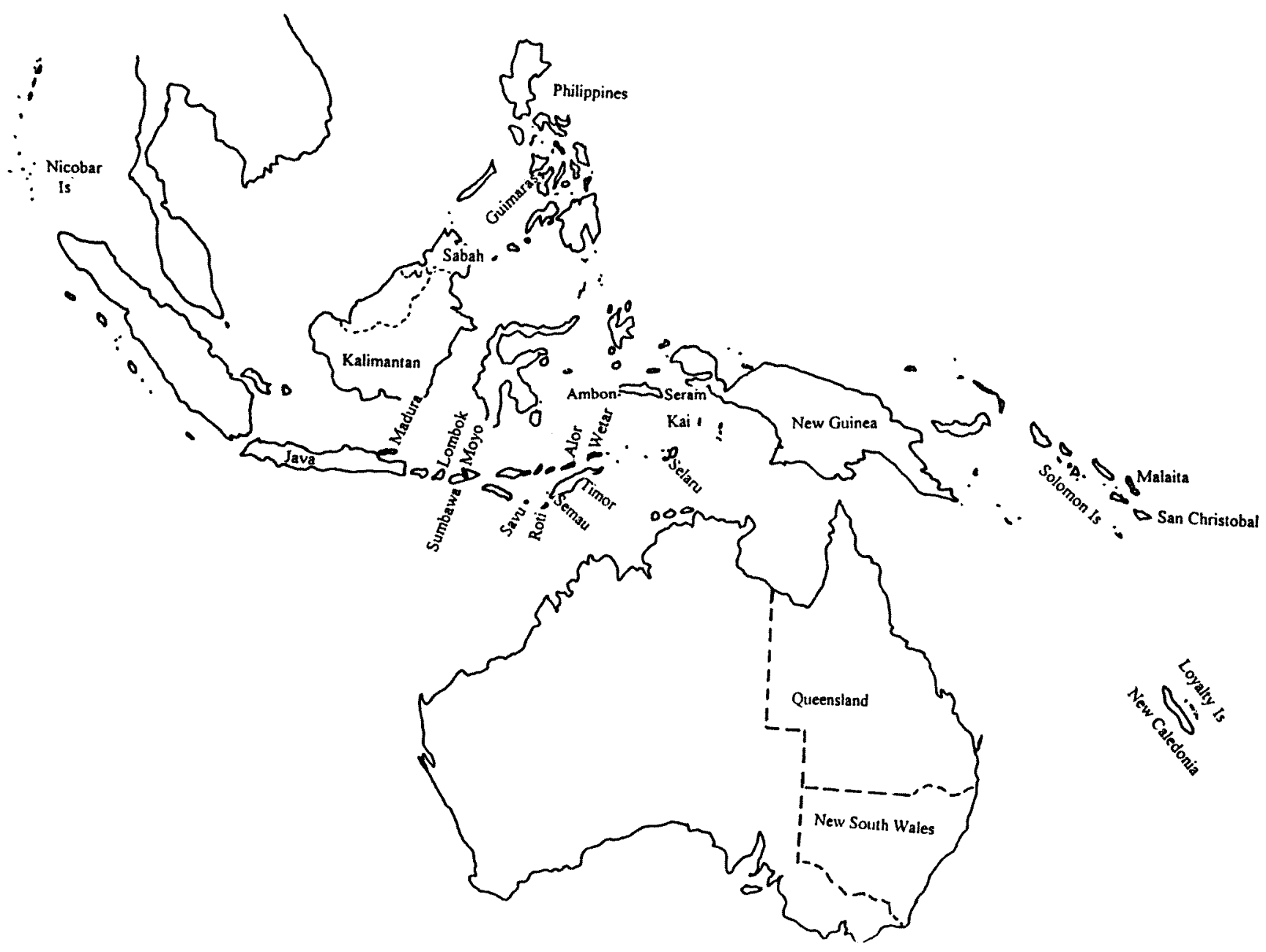

Figure 1 Map showing locality names referred to in text.

author placed shortridgei in synonymy with paululus.

Expeditions throughout Java, Nusa Tenggara and Maluku Tenggara by staff from the Western Australian Museum and Museum Zoologicum Bogoriense between 1987-1994 resulted in an extensive collection of small Miniopterus that were representative of $M$. australis and $M$. pusillus (sensu Hill in Corbet and Hill 1992). These specimens came from the islands of: Java, Madura, Lombok, Sumbawa, Moyo, Alor, Wetar, Kai, Selaru (Tanimbar), Timor, Semau, Roti, Savu and Seram. These recent collections, in conjunction with existing collections from Borneo, Philippines, Papua New Guinea and Australia (Queensland and New South Wales), (see Figure 1 for collection localities) allow for a fresh appraisal of the taxonomy of small Miniopterus in this region. This paper reports on such an appraisal, particularly with the view of evaluating the uncertain taxonomic status of most populations and particularly of the previously unreported populations from Madura, Lombok, Sumbawa, Moyo, Alor, Wetar, Selaru, Semau, Roti and Savu islands (Figure 1).

\section{MATERIALS AND METHODS}

For the morphometric analyses, 366 adult Miniopterus specimens from Java, Borneo, 13 islands in Nusa Tenggara and Maluku Tenggara, Philippines, Papua New Guinea and Australia were measured and analysed statistically, using both univariate and multivariate analyses.

Adult condition was judged to be when there was no swelling of the epiphyses of the wing metacarpals or phalanges. Adults were further subdivided into young adults (no wear at distal end of upper canine, or if worn dentine not exposed) and old adults (worn upper canine with dentine exposed).

The measurements (all in $\mathrm{mm}$ ) were recorded from each specimen using vernier calipers as follows: GSL, greatest skull length; BCL, basicranial length; PL, palatal length; ICD, intercochlear distance; MW, mastoid width; MFB, mesopterygoid fossa breadth; $\mathrm{CH}$, cranial height; LIB, least interorbital breadth; $\mathrm{ZW}$, zygomatic width; $\mathrm{BB}$, braincase breadth; $\mathrm{C}^{1} \mathrm{M}^{3}$, upper maxillary tooth row cusp length; $\mathrm{C}^{1} \mathrm{C}^{1}$, distance between upper canines at basal labial surface; $\mathrm{M}^{3} \mathrm{M}^{3}$, distance between 
upper third molar cusps, at labial surface; $\mathrm{M}^{2} \mathrm{~L}$, upper second molar cusp length; $\mathrm{M}^{2} \mathrm{~B}$, upper second molar cusp breadth; $\mathrm{I}_{1} \mathrm{M}_{3}$, lower tooth row cusp length and DL, dentary length from condyle to anterior most point; SVL, snout to anus length; TVL, distal point of tail to anus length; EL, ear length; TIB, tibia length; FA, forearm length; D2-5MC, digits 2-5 metacarpal length; and D3Pl-3, digit 3 phalanx 1-3 length.

Sexual dimorphism of 17 cranial, dentary and dental characters (referred to collectively as skull characters) and 12 external body characters of Miniopterus specimens was investigated by standard multiple regression (where all effects were assessed simultaneously) of each character on sex and population, with skull and external body characters run separately. Specimens preserved and lodged in the Western Australian Museum's collection from each island, and from Queensland and New South Wales (Australia) were regarded as separate populations. Additionally two distinct forms of small Miniopterus were recognised a priori as occurring on some islands (Java, Lombok, Sumbawa, Alor, Selaru, Semau, Roti and Seram). Where this occurred, each form on the island was considered a separate population. These forms were clearly recognisable as a larger and smaller form.

Only the populations represented by both the two adult age types and both sexes present were included in these analysis. For the skull characters these were: Java (large form), Lombok island (small), Lombok island (large) Sumbawa island (small), Semau (small), Savu, Selaru (small) and Queensland. For the external characters these populations were: Borneo, Sumbawa (small), Lombok (large), Semau (small), Savu, Selaru (large), Queensland and New South Wales. The difference in the populations used in these analyses results from damage to skulls but not external body characters, or the converse. Graphical inspection of raw data using plots from regression analyses gave no indication of heteroscedasticity.

After first examining for the influence of adult age and/or sex on characters Discriminant Function Analyses (DFA) were run separately for measurements of skull and external characters. Characters that were age or sex dependent, or which had a significant interaction between age and sex, or which had a number of missing cases, were excluded from these analyses.

Populations, as identified above, that had clearly overlapping clusters in discriminant function space were combined as a group. Groups so recognised were then run again with DFA but using a subset of five most influential characters; these subsets were chosen so as to minimise the value of Wilks' Lambda (How et al. 1996). In all cases this subset of five characters provided a similar grouping of islands to that when the DFA used the full set of characters. For this reason only the DFA based on such a subset of characters are presented.

Statistical analyses were performed using SPSSPC+ (Norusis, 1986).

Specimens examined were from a number of museums. These museums are denoted by a prefix code before the specimen number as follows: WAM, Western Australian Museum; JM, Queensland; M, Australian Museum; and CM, CSIRO, Australia. Most specimens have both a skull and spirit carcase; those affixed with 'S' have a skull only and with ' $E$ ', spirit carcase only.

\section{RESULTS}

\section{Multiple regressions}

Because of the number of associations tested, the level of statistical significance is set at $P<0.01$.

Skull characters - There were significant interactions in the full model in two characters: palatal length (sex. age. population and sex. population) and $\mathrm{M}^{2}$ breadth (age. population). Only cranial height was sexually dimorphic with males of all populations being on average larger $\left(\mathrm{F}_{1,104}=\right.$ 7.304, $\mathrm{P}=0.008$ ). Age was not significantly associated with any character. All characters differed significantly at $\mathrm{P}<0.001$ between populations, except greatest skull length; the characters with the highest $F$ values were $C^{1} M^{3}$ length, $\mathrm{M}^{3} \mathrm{M}^{3}$ distance $\mathrm{C}^{1} \mathrm{C}^{1}$ distance and dentary length (Table 1a).

External body characters - There were no significant interactions in the full model, nor was there any significant association of any of the characters with either sex or age. However, all characters were highly significantly $(P<0.001)$ associated with population, particularly tibia length and digit 3 and 5 metacarpal lengths (Table $1 b$ ).

\section{Discriminant Function Analyses (DFA)}

(a) Skull characters - five skull characters were omitted from all DFA. Two of these were omitted because a number of individuals had missing values (mesopterygoid fossa breadth and zygomatic width), two because of significant interactions between main effects (palatal length and $\mathrm{M}^{2}$ breadth) and cranial height and one because it was sexually dimorphic.

A DFA using a subset of five of the remaining 12 characters $\left(\mathrm{M}^{3} \mathrm{M}^{3}\right.$ distance, braincase breadth, $\mathrm{C}^{1} \mathrm{M}^{3}$ length, $\mathrm{C}^{1} \mathrm{C}^{1}$ distance and dentary length) was run for all populations. This analysis extracted four significant functions which explained a total of $98.6 \%$ of the variation and allowed $40.4 \%$ of specimens to be allocated to their correct group. Three major groupings of these populations were apparent from the plot of Functions 1 and 2 (Figure 2a). Combinations of other Discriminant Functions 

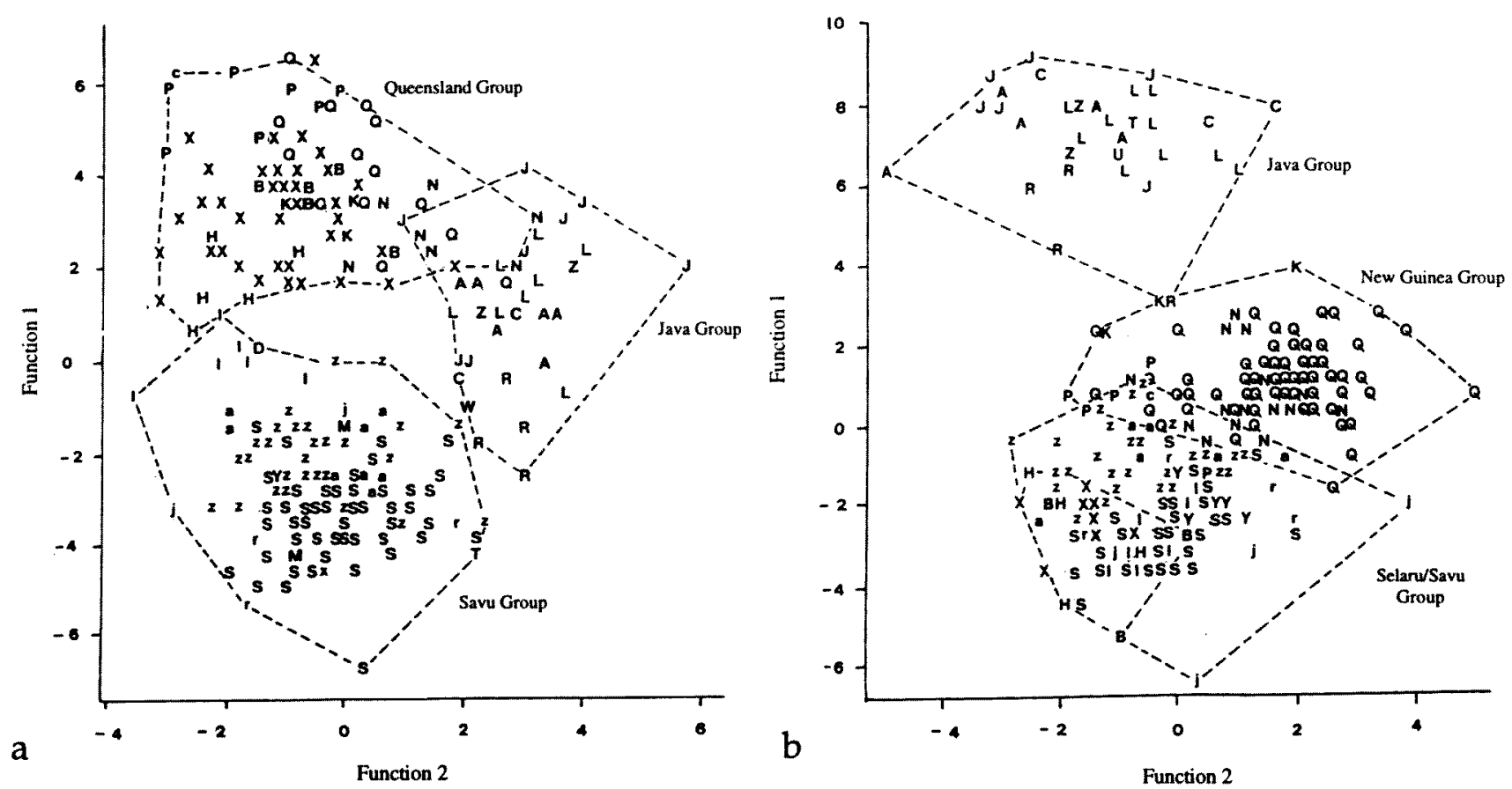

Figure 2 Plot of DFA Functions 1 and 2 based on five (a) skull and (b) external body characters and all localities for adult Miniopterus [15 Indonesian islands, Philippines, Papua New Guinea and Australia (Queensland and New South Wales separately)]. Locality codes are as follows (when two forms are on the same island the larger form is capitalised): Borneo, B; Java, J and j; Madura, D; Lombok, L and l; Sumbawa, Z and z; Moyo, M; Alor, A and a; Wetar, W; Selaru, X and X; Kai, K; Seram, C and c; Timor, T; Semau, Y; Roti, R and r; Savu S; Philippines, H; Papua New Guinea, P; Queensland, Q; and New South Wales, N.

do not clarify further these major groups. These groups are: Java Group Uava (large), Alor (larger form), Seram (large), Lombok (large), Roti (large) and Sumbawa (large)]; Queensland Group [Queensland, New South Wales, Papua New Guinea, Borneo, Seram (small form), Philippines, Kai, Selaru (large)]; and Savu Group [Savu, Alor (small), Madura, Java (small), Lombok (small), Moyo, Roti (small), Timor, Wetar, Selaru (small), Semau and Sumbawa (small)].

The DFA on external body characters (see below) indicated that two clear sub-groupings of populations occurred in the Queensland Group. Consequently, after dividing the Queensland Group into two Groups (New Guinea and Selaru), a DFA was run using a subset of five skull characters (see Table 2a) and the following four a priori population groupings: Java Group (as above); New Guinea Group (Papua New Guinea, Queensland, New South Wales, Kai and Seram (small); Selaru Group [Selaru (large), Philippines and Borneo]; and Savu Group (as above).

This DFA extracted three significant functions. Function 1, which separated the Savu Group from the other groups, explained $83.2 \%$ of the variance (Figure 3a). The canonical variate coefficients with the highest values on Function 1 were braincase breadth, $C^{1} M^{3}$ length and $M^{3} M^{3}$ distance (Table $2 a$ ). Function 2, which separated the Java Group from the Selaru Group, also partially separated the Java Group, explaining $15.6 \%$ of the variance. The coefficients with the highest values on Function 2 were braincase breadth, $\mathrm{M}^{3} \mathrm{M}^{3}$ distance and $\mathrm{M}^{2}$ length. Plots of other combinations of Functions 1 to 3 did not further clarify these four groupings.

A total of $88.5 \%$ of individuals were allocated to their correct population grouping. Only four of the 115 individuals from the Savu Group were misclassified; three to the Java Group and one to the Selaru Group. Three of the 28 Java Group individuals were misclassified; one to the Selaru Group and two to the New Guinea Group. Most misclassifications were between the New Guinea and Selaru Group: with seven of 44 individuals from the Selaru Group to the New Guinea Group and seven of the 32 individuals from the New Guinea Group to the Selaru Group and five to the Java Group.

(b) External body characters - Snout to vent length and tail length were omitted from all DFA because these two measurements could not be recorded with the accuracy of other body measurements.

A DFA using a subset of five of the remaining characters (tibia length, digit 5 metacarpal length, digit 3 phalanx 2 and 3 lengths and ear length) was run for all populations. This analysis extracted four significant functions and allowed $46.1 \%$ of specimens to be allocated to their correct group. 
Table 1 The F-values from multiple regressions on sex, age and population and their interactions for eight populations of adult Minioptertus (see text) from Indonesia, Philippines, New Guinea and Australia. (a) skull characters and (b) external body characters. There were no significant interactions for external body characters. Probability levels are: ${ }^{*}, \mathrm{P}<0.05 ;{ }^{* *}, \mathrm{P}<0.01$; and ${ }^{* *}, \mathrm{P}<0.001$.

\begin{tabular}{|c|c|c|c|c|c|c|c|}
\hline \multirow[b]{2}{*}{ Character } & \multicolumn{3}{|c|}{ Main Effects } & \multicolumn{4}{|c|}{ Interactions } \\
\hline & sex & age & population & $\begin{array}{l}\text { sex. age. } \\
\text { population }\end{array}$ & sex. age. & $\begin{array}{c}\text { sex. } \\
\text { population }\end{array}$ & $\begin{array}{c}\text { age. } \\
\text { population }\end{array}$ \\
\hline GSL & 0.340 & 0.047 & 0.659 & 0.076 & 0.036 & 0.118 & 0.0310 \\
\hline $\mathrm{BCL}$ & 3.639 & 0.297 & $7.206^{* * *}$ & 1.400 & 0.354 & 0.611 & 0.559 \\
\hline PL & 0.016 & 0.430 & $9.126^{* * *}$ & $7.335^{* * *}$ & 0.988 & $3.584^{* *}$ & 1.627 \\
\hline ICD & 0.709 & 1.003 & $4.647^{* * *}$ & 0.912 & 0.181 & 0.878 & 0.516 \\
\hline MW & $5.844^{*}$ & $4.870^{*}$ & $28.130^{* * *}$ & 0.351 & 0.002 & 1.123 & 0.974 \\
\hline MFB & 2.294 & $0.480^{*}$ & $8.626^{* * *}$ & 0.934 & 0.475 & 1.809 & 0.753 \\
\hline $\mathrm{CH}$ & $7.304^{* *}$ & 0.409 & $33.762^{* * *}$ & 0.157 & 2.238 & 1.220 & 0.896 \\
\hline LIB & 1.068 & 0.352 & $12.040^{* * *}$ & 1.012 & 1.324 & 1.327 & 0.755 \\
\hline $\mathrm{ZW}$ & 3.881 & 1.106 & $40.474^{* * *}$ & 0.423 & 0.032 & 1.215 & 0.897 \\
\hline BB & 3.184 & 0.891 & $32.967^{* * *}$ & 1.800 & 0.012 & 1.432 & 0.993 \\
\hline $\mathrm{C}^{1} \mathrm{M}^{3}$ & 3.916 & 1.169 & $64.008^{* * *}$ & 0.889 & 1.856 & 1.076 & 2.118 \\
\hline $\mathrm{C}^{1} \mathrm{C}^{1}$ & 2.833 & 0.899 & $40.560^{* * *}$ & 0.433 & 0.827 & $2.811^{*}$ & $2.433^{*}$ \\
\hline $\mathrm{M}^{3} \mathrm{M}^{3}$ & 0.753 & 0.139 & $61.856^{* * *}$ & 0.807 & 2.500 & 1.375 & 1.421 \\
\hline $\mathrm{M}^{2} \mathrm{~L}$ & 0.346 & 0.023 & $15.718^{* * *}$ & 0.996 & $5.135^{*}$ & 1.606 & 1.680 \\
\hline $\mathrm{M}^{2} \mathrm{~B}$ & 1.720 & 0.962 & $13.997^{* * *}$ & 1.513 & 2.524 & 1.276 & $4.315^{* *}$ \\
\hline $\mathrm{I}_{1} \mathrm{M}_{3}$ & 0.000 & 0.191 & $4.366^{* * *}$ & 0.051 & 0.241 & 0.160 & 0.306 \\
\hline $\mathrm{DL}^{3}$ & 2.950 & 0.287 & $40.254^{* * *}$ & 0.197 & 0.099 & 1.145 & 0.986 \\
\hline d.f & 1,104 & 1,104 & 7,104 & 3,104 & 1,104 & 6,104 & 6,104 \\
\hline
\end{tabular}

Table 1b.

\begin{tabular}{lccc}
\hline \multicolumn{4}{c}{ Main effects } \\
Character & Sex & Age & Population \\
\hline SVL & 0.084 & 0.414 & $4.921^{* * *}$ \\
TV & 0.164 & 0.003 & $20.452^{* * *}$ \\
EL & 0.001 & 0.175 & $6.257^{* * *}$ \\
TIB & $4.358^{*}$ & 2.670 & $110.245^{* * *}$ \\
FA & 0.150 & 0.183 & $52.655^{* * *}$ \\
D2MC & 0.040 & 0.352 & $49.097^{* * *}$ \\
D3MC & 1.134 & 1.779 & $75.844^{* * *}$ \\
D3P1 & 0.005 & 0.243 & $10.850^{* * *}$ \\
D3P2 & 2.551 & 2.308 & $32.301^{* * *}$ \\
D3P3 & 0.000 & 0.004 & $15.092^{* * *}$ \\
D4MC & 0.005 & 0.042 & $5.748^{* * *}$ \\
D5MC & 0.245 & 0.419 & $99.903^{* * *}$ \\
d.f & 1,163 & 1,163 & 7,163 \\
\hline
\end{tabular}

Three major groupings of these populations are apparent and these are displayed in a plot of Functions 1 and 2 (Figure 2b). These major population groupings were (using the above terminology): Java Group; New Guinea Group; and Selaru Group and Savu Group (combined).

However, because individuals in the Savu group were distinguishable on skull characters from the Selaru Group, the DFA was based on a subset of five external body characters (see Table $2 b$ ) and the four a priori groups of Java, New Guinea, Selaru and Savu. This analysis extracted three significant functions. Function 1, which explained $82.2 \%$ of the variance, separated the New Guinea Group from the other groups and partially separated the Selaru Group from the Java Group (Figure $3 b$ ). The characters with high coefficient values on Function 1 were tibia length and digit 5 metacarpal length (Table $2 \mathrm{~b}$ ). Function 2, which partially separated the Java Group from the other groups, explained 14.1\% of the variance. The characters with high coefficient values on Function 2 were tibia length, forearm length, digit 5 metacarpal length, and digit 3 phalanx 2 length. A total of $85.4 \%$ of individuals were classified to their correct population with, as expected, most misclassifications between the Savu and Selaru Groups. In the Java Group, 91\% of the 104 individuals were correctly classified; misclassifications were $3 \%$ to the Savu Group and $6 \%$ to the Selaru Group. Only one of the $34 \mathrm{New}$ Guinea Group individuals was misclassified (to the Savu Group). In the Savu Group, $81 \%$ of the 138 individuals were correctly classified; misclassifications were $6 \%$ to the Java Group and $13 \%$ to the Selaru Group. In the Selaru Group, 73\% of the 33 individuals were correctly classified; misclassifications were $3 \%$ to the Java Group and $24 \%$ to the Savu Group.

\section{Morphological variation within major population groups}

Considerable subclustering was apparent among populations within the major population groups 
Table 2 Standardised and unstandardised (in brackets) canonical variate coefficients from DFA based on five selected characters and four a priori population groups (Java, New Guinea, Selaru and Savu, see text) of adult Miniopterus. (a) skull and (b) external body characters. Character codes described in text.

\begin{tabular}{llccc}
\hline Table 2(a) & Function 1 & Function 2 & Function 3 \\
\hline & Character & Fuc & $-1.0065(-9.2902)$ \\
$\mathrm{M}^{3} \mathrm{M}^{3}$ & $0.4561(4.2094)$ & $0.5107(4.7141)$ & $-0.0011(-0.0090)$ \\
$\mathrm{BB}$ & $0.5034(4.0535)$ & $-0.8807(-7.0924)$ & $0.9945(9.6701)$ \\
$\mathrm{CM}^{1}$ & $0.4950(4.8138)$ & $0.0246(0.2390)$ & $0.2347(5.9744)$ \\
$\mathrm{M}^{2} \mathrm{~L}$ & $0.0671(1.7091)$ & $0.4871(12.4004)$ & $0.1357(0.9178)$ \\
$\mathrm{BCL}$ & $-0.3644(-2.4652)$ & $-0.0583(-0.3945)$ & -11.4014 \\
Constant & -64.9332 & 9.2704 & 1.2 \\
Variance explained (\%) & 83.2 & 15.6 & \\
\hline
\end{tabular}

Table 2(b)

\begin{tabular}{lccc} 
Character & Function 1 & Function 2 & Function 3 \\
\hline D5MC & $0.4417(0.5051)$ & $0.8880(1.0155)$ & $-0.6030(-0.6896)$ \\
TIB & $0.7515(1.3791)$ & $-1.2043(-2.2101)$ & $0.0481(0.0882)$ \\
EL & $-0.0805(-0.1534)$ & $0.2661(0.5069)$ & $0.8922(1.6992)$ \\
D3P2 & $-0.0606(-0.0564)$ & $-0.6566(-0.6114)$ & $0.1673(0.1558)$ \\
FA & $-0.0698(-0.0677)$ & $0.9035(0.8776)$ & $0.4292(0.4169)$ \\
Constant & -31.9806 & -20.2784 & -16.5598 \\
Variance explained (\%) & $\mathbf{8 2 . 2}$ & 14.1 & 3.7 \\
\hline
\end{tabular}

(Java, New Guinea, Selaru and Savu), both in skull and or external body characters. This variation was also examined using DFA.

\section{The Java Group}

Skull characters - a DFA based on all the Java Group populations and using a subset of five skull characters extracted two significant functions which combined explained $85 \%$ of the variance with $68.6 \%$ of individuals allocated to their correct population; no clear subgroups of these populations was detected.

External body characters - a DFA based on all Java Group populations and using a subset of five external body characters (ear length, digit 3 phalanx 1-3 and digit 5 metacarpal length) extracted two significant functions in which $74 \%$ of individuals were allocated to their correct population. The

Table 3 Standardised and unstandardised (in brackets) canonical variate coefficients from DFA based on five selected external body characters and three $a$ priori populations subgroups (Western, Southeastern and Seram) of adult Miniopterus in the Java Group (see text).

\begin{tabular}{lcc}
\hline Character & Function 1 & Function 2 \\
\hline EL & $0.9077(3.1093)$ & $0.6362(2.1794)$ \\
D3P3 & $0.7261(1.5434)$ & $0.0583(0.1240)$ \\
D5MC & $0.9224(0.8365)$ & $-1.2242(-1.1102)$ \\
D3P1 & $-0.6927(-1.6310)$ & $0.5464(1.2867)$ \\
TIB & $-0.3667(-0.3847)$ & $0.4827(0.5064)$ \\
Constant & -46.8639 & -6.0525 \\
Variance explained $(\%)$ & 74.7 & 25.3 \\
\hline
\end{tabular}

configuration of these populations in discriminant function space was very similar to Figure 4 but with a marginal overlap between the populations nominated as the western and southeastern forms on that figure. From this DFA the following population groups were recognised: Western subgroup (Java, Lombok, Sumbawa); Southeastern subgroup (Alor and Roti); and Seram subgroup (Seram island)

A DFA based on these three subgroups (Western, Southeastern and Seram) and using a subset of five external body characters (see Table 3 ) extracted two significant functions. Function 1, which explained $74.7 \%$ of the variance, separated the Seram subgroup from both the Western and Southeastern subgroups (Figure 4). All characters, except tibia length, had high canonical variate coefficients on Function 1 (Table 3). Function 2, which explained $25.3 \%$ of the variance, separated the Southeastern subgroup from both the Western and Seram subgroups. The characters with high coefficient values on Function 2 were digit 5 metacarpal length, ear length and digit 3 phalanx 1 length. A total of $94.1 \%$ of individuals were classified to their correct population subgroup. Misclassification only occurred in the Southeastern subgroup where two of the 10 individuals in this group were allocated to the Western subgroup.

\section{The New Guinea Group}

Skull Characters - a DFA based on all populations in the New Guinea Group and using a subset of five skull characters (see Table 4a) extracted three significant functions which explained a combined 

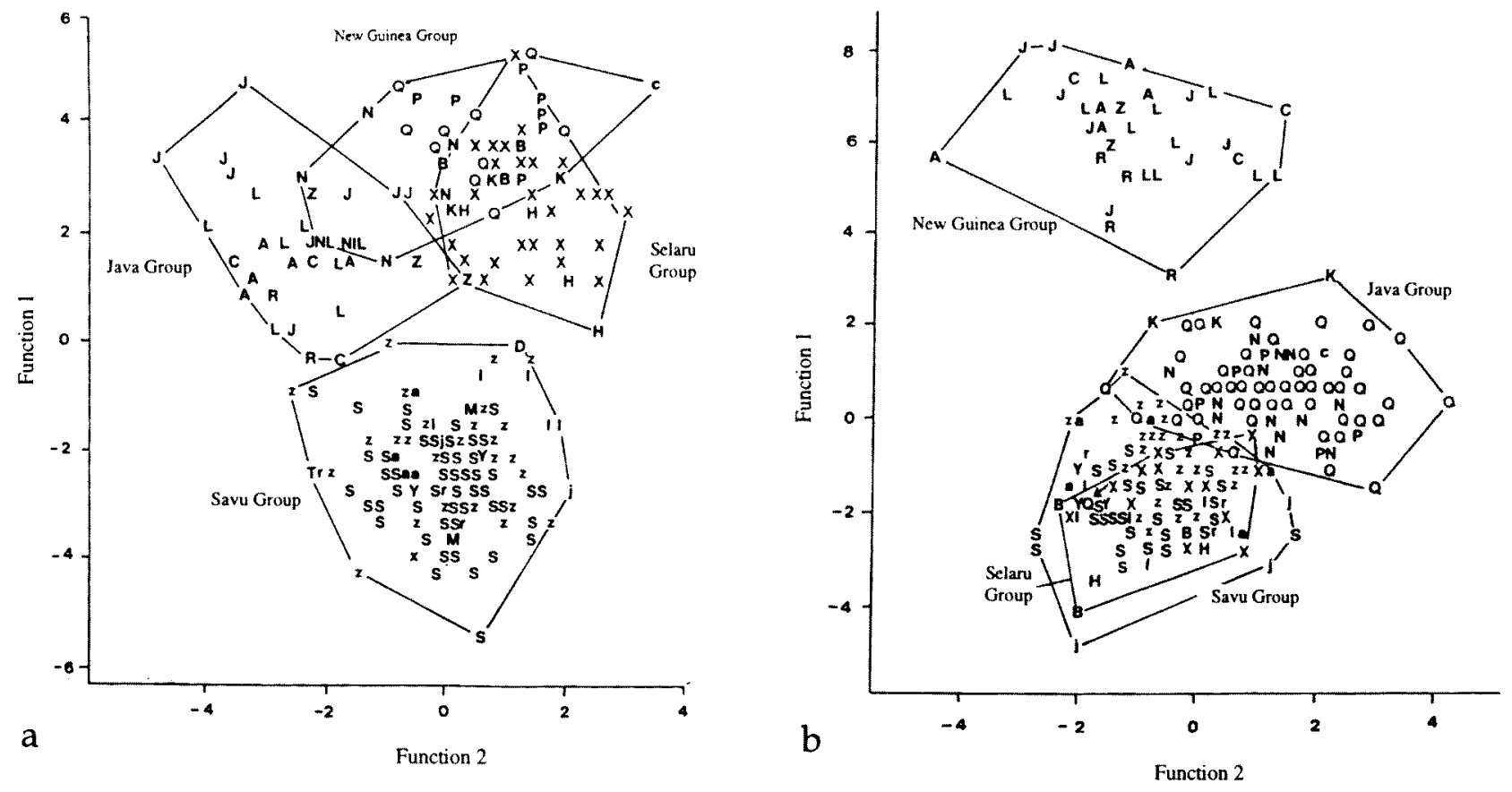

Figure 3 Plot of DFA Functions 1 and 2 based on five (a) skull (b) external body characters and four a priori groupings of localities (Java, New Guinea, Selaru and Savu Groups, see text) of adult Miniopterus. Locality codes as for Figure 2.

$97.9 \%$ of the variance. Only $77.1 \%$ of individuals were classified to their correct population subgroup. Function 1, which explained $58.5 \%$ of the variance, separated the Papua New Guinea

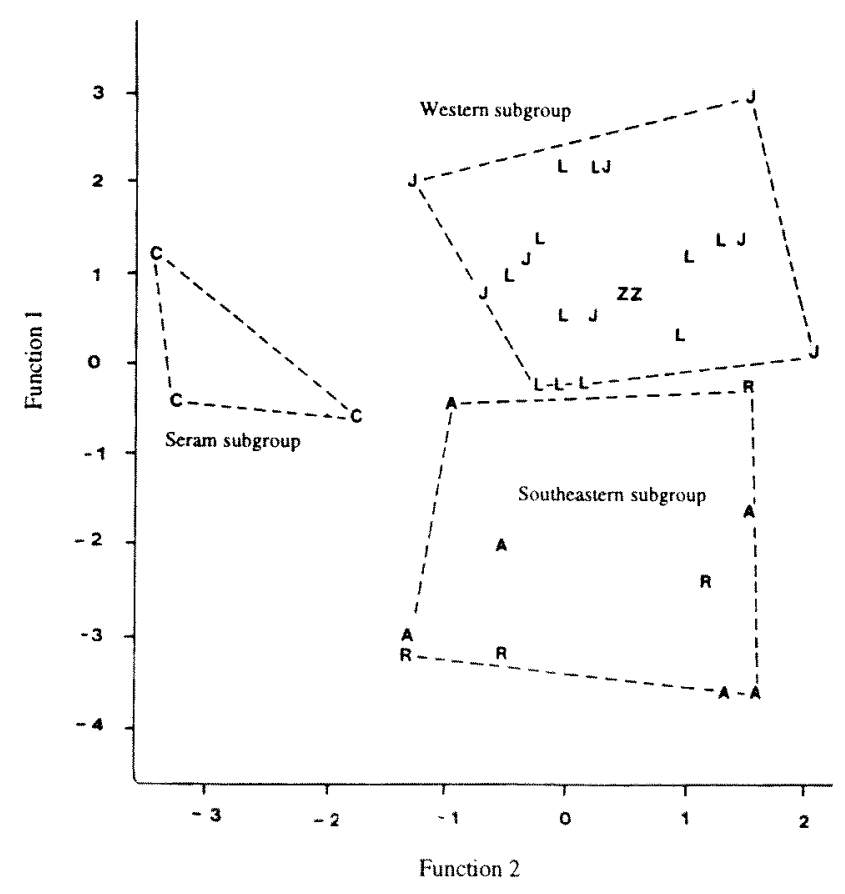

Figure 4 Plot of DFA Functions 1 and 2 based on five external body characters and all Java Group populations (see text) for adult Miniopterus. Locality codes as for Figure 2. Three subgroups of populations are apparent from this analysis (Western, Southeastern and Seram. population from both the Kai and New South Wales populations (Figure 5a). The characters with high $(>0.5)$ coefficient values were $C^{1} M^{3}$ length, dentary length and greatest skull length (Table 4a). Function 2, which explained $24.9 \%$ of the variance, separated the Kai population from the others. The character with the highest coefficient value on Function 2 was intercochlear distance (Table 4a). Function 3, which explained $14.5 \%$ of the variance, did not noticeably separate further these populations.

External characters - a DFA based on all populations in the New Guinea Group and using a subset of five external body characters (see Table 4b) extracted three significant functions which combined explained $97.7 \%$ of the variance. Only $56.7 \%$ of individuals were classified to their correct population. Function 1, which explained $65.4 \%$ of the variance, separated the Papua New Guinea population from the Kai and New South Wales populations and partially so from the Queensland population (Figure $5 \mathrm{~b}$ ). The characters with high coefficients $(>0.5)$ on Function 1 were digit 3 phalanx 1 length, ear length and tibia length (Table 4 b). Function 2, which explained $24.3 \%$ of the variance, separated the Kai population from the other populations (Figure $5 b$ ). The character with the highest coefficient on Function 2 was tibia length (Table $4 \mathrm{~b}$ ). Function 3, which explained 9.3\% of the variance did not noticeably further separate these groups.

The above analyses indicated that while the Papua New Guinea population had diverged from the New South Wales population; the Queensland population was both geographically and 

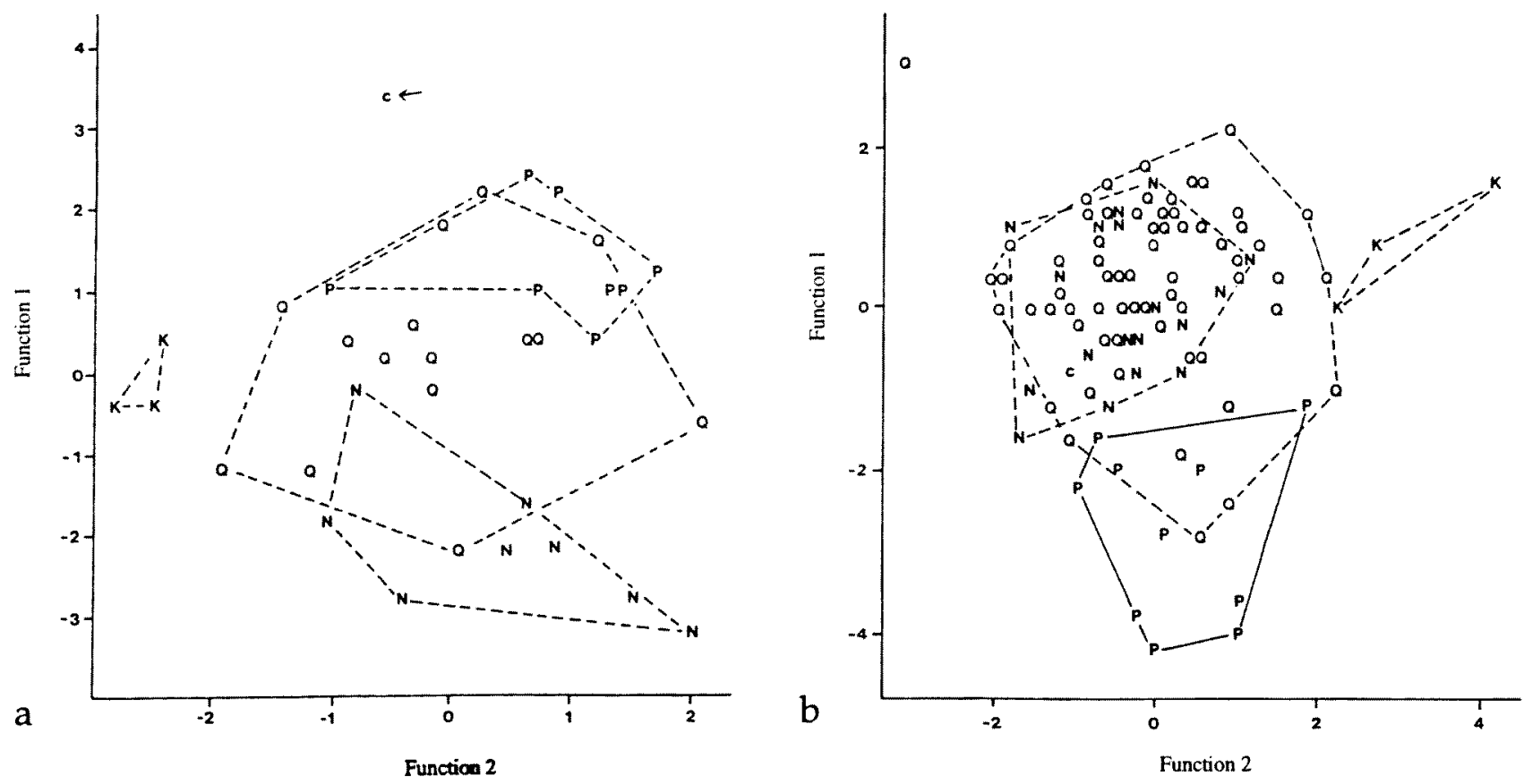

Figure 5 Plot of DFA Functions 1 and 2 based on five (a) skull and (b) external body characters and the four New Guinea Group populations (New Guinea, Queensland, New South Wales and Kai island) for adult Miniopterus. Locality codes as for Figure 2.

morphologically intermediate between them. The Kai population, represented by only three specimens, appeared to form a subgroup separate from the Papua New Guinea, Queensland and New South Wales populations.

\section{The Selaru Group}

Skull characters - a DFA based on the three populations of Borneo, Philippines and Selaru as $a$ priori groups and using a subset of five skull characters (see Table 5a) extracted two significant functions. Function 1, which explained $91.9 \%$ of the variance, separated all three populations (Figure 6a). All five characters had high coefficient values on Function 1 (Table 5a) which suggested that overall skull size was important in separating these

Table 4 Standardised and unstandardised (in brackets) canonical variate coefficients from DFA based on five selected characters and four populations (Kai, New Guinea, Queensland and New South Wales) of adult Miniopterus in the New Guinea Group (see text). (a) skull and (b) external body characters.

\begin{tabular}{llccc}
\hline Table 4a & & & & \\
& Character & Function 1 & Function 2 & Function 3 \\
\hline & CM $^{3}$ & $0.6378(7.4690)$ & $0.4619(5.4096)$ & $-1.1766(-13.7785)$ \\
& GSL & $-0.5034(-3.2171)$ & $0.4439(2.8372)$ & $1.2120(7.7464)$ \\
& ICD & $-0.3369(-4.7289)$ & $0.6065(8.5132)$ & $-0.5549(-7.7884)$ \\
& M'L & $0.2055(6.5967)$ & $-0.4442(-14.2600)$ & $0.3979(12.7725)$ \\
& DL & $0.6463(4.4046)$ & $-0.1149(-0.7831)$ & $0.3511(2.3927)$ \\
& Constant & -42.0322 & -53.1482 & -64.9240 \\
& Variance explained (\%) & 58.5 & 24.9 & 14.5 \\
\hline \multirow{5}{*}{ Table 4b } & & & \\
& & & & \\
& Character & Function 1 & Function 2 & Function 3 \\
\hline & D3P3 & $0.8337(1.7967)$ & $-0.0900(-0.1940)$ & $0.3421(0.7371)$ \\
TIB & $0.5286(1.3082)$ & $0.7407(1.8334)$ & $-0.2608(-0.6454)$ \\
& EL & $-0.5818(-0.9738)$ & $-0.0746(-0.1249)$ & $-0.1564(-0.2617)$ \\
D3P2 & $-0.1913(-0.2285)$ & $-0.2253(-0.2691)$ & $1.0794(1.2896)$ \\
& FA & $-0.3811(-0.4763)$ & $0.4637(0.5796)$ & $0.0278(0.0347)$ \\
Constant & 2.0761 & -42.6074 & -25.740 \\
Variance explained (\%) & 65.4 & 24.3 & 9.3 \\
\hline
\end{tabular}


Table 5 Standardised and unstandardised (in brackets) canonical variate coefficients from DFA based on five selected characters and three populations (Borneo, Philippines and Selaru) of adult Minioptertus in the Selaru Group (see text). (a) skull and (b) external body characters

\begin{tabular}{lcc}
\hline $\begin{array}{l}\text { Table 5a } \\
\text { Character }\end{array}$ & Function 1 & Function 2 \\
\hline $\mathrm{I}_{\mathrm{M}}$ & $0.7940(8.0915)$ & $0.5475(5.5792)$ \\
$\mathrm{BB}$ & $-0.9966(-7.7188)$ & $1.0001(7.7461$ \\
$\mathrm{MW}$ & $0.8575(6.2331)$ & $-0.4952(-3.5995)$ \\
$\mathrm{M}^{3} \mathrm{M}^{3}$ & $-0.8138(-8.5414)$ & $0.1177(1.2358)$ \\
$\mathrm{C}^{1} \mathrm{C}^{1}$ & $0.7086(7.3221)$ & $-0.1008(-1.0413)$ \\
Constant & -26.8162 & -67.7533 \\
Variance explained $(\%)$ & 91.9 & 8.1 \\
\hline
\end{tabular}

\section{Table 5b}

Character

Function $1 \quad$ Function 2

\begin{tabular}{lcc}
\hline EL & $0.5450(1.3966)$ & $0.0426(0.1091)$ \\
D3P1 & $-0.3955(-0.8599)$ & $0.8448(1.8368)$ \\
D3P3 & $0.6162(0.8501)$ & $-0.6363(-0.8780)$ \\
D2MC & $-1.1344(-1.2697)$ & $-0.2616(-0.2928)$ \\
D3P2 & $0.8204(2.4340)$ & $0.4129(1.2249)$ \\
Constant & -28.7462 & 13.3848 \\
Variance explained (\%) & 86.8 & 13.2 \\
\hline
\end{tabular}

populations. Function 2, which explained $8.1 \%$ of the variance, separated the Borneo and Philippine populations. The characters with high $(>0.5)$ coefficients on Function 2 were braincase breadth and $\mathrm{I}_{1} \mathrm{M}_{3}$ length. A total of $94.1 \%$ of individuals were classified to their correct population. All individuals in the Borneo and Philippine populations and all but three of the 42 individuals from the Selaru population were correctly classified; these three Selaru individuals were misclassified to the Philippine population.

External characters- a DFA, based on the three populations of Borneo, Philippines and Selaru as $a$ priori groups and using a subset of five external body characters (see Table $5 b$ ), extracted two significant functions. Function 1, which explained $86.8 \%$ of the variance, separated the Selaru population from both the Philippine and Borneo populations (Figure 6b). All five characters, except digit 3 phalanx 1 length, had high (>.05) coefficient values (Table $5 b$ ). Function 2 , which explained $13.2 \%$ of the variance, separated the Borneo and Philippine populations. The characters with high $(>0.5)$ coefficients on Function 2 were digit 3 phalanx 1 and 3 . A total of $97 \%$ of individuals were classified to their correct populations. All individuals in the Borneo and Philippine populations were correctly classified; a single Selaru individual was misclassified to the Borneo population.

\section{The Savu Group}

Skull characters - a DFA based on all populations in the Savu Group and using a subset of five characters (dentary length, $\mathrm{M}^{3} \mathrm{M}^{3}$ distance, intercochlear distance, mastoid width and $\mathrm{C}^{1} \mathrm{M}^{3}$ length) extracted four significant functions, which combined explained $98.1 \%$ of the variation. There
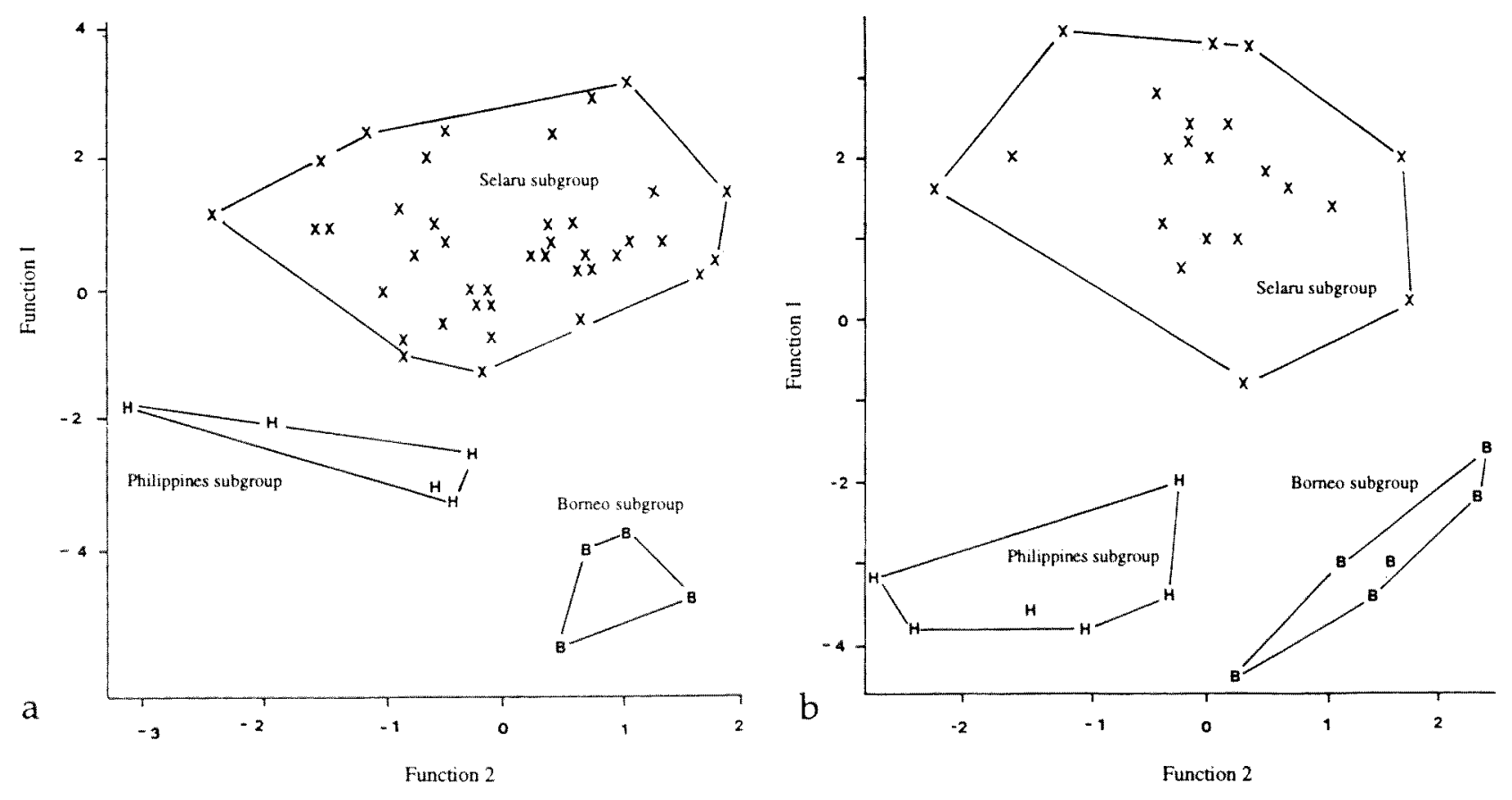

Figure 6 Plot of DFA Functions 1 and 2 based on five (a) skull and (b) external body characters and the three Selaru Group populations (Borneo, Philippines and Selaru) for adult Miniopterus. Locality codes as for Figure 2. 

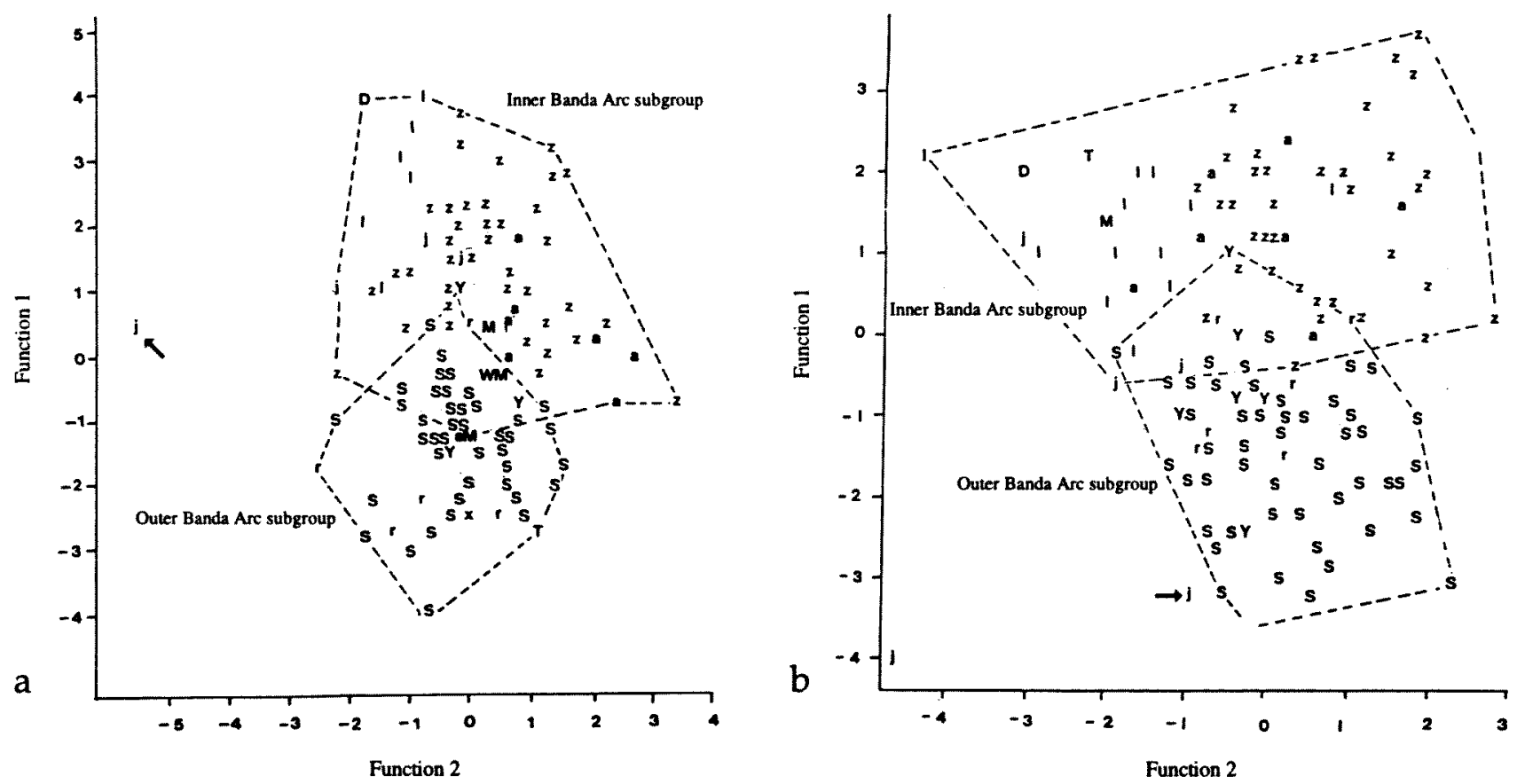

Figure 7 Plot of DFA Functions 1 and 2 based on five (a) skull and (b) external body characters and all the island populations in the Savu Group (see text) for adult Miniopterus. Locality codes as for Figure 2.

was, however, considerable overlap between these populations, with only $45.2 \%$ of individuals classified to their correct population. The plots of combinations of Functions 1 to 3 , which combined explained $92.5 \%$ of the variance, indicated that some morphological substructuring occurs among these populations. For example, Function 1 which

Table 6 Standardised and unstandardised (in brackets) canonical variate coefficients from DFA based on five selected characters and two a priori subgroupings of the 12 island populations (Inner and Outer Banda Arc, with Wetar island included in the latter subgroup) of adult Miniopterus in the Savu Group (see text). (a) skull and (b) external body characters.

\begin{tabular}{llc}
\hline Table 6a & & Function 1 \\
& Character & $0.6507(4.4852)$ \\
& DL & $0.5579(6.8625)$ \\
ICD & $-0.7147(-5.8647)$ \\
MW & $0.6320(8.0696)$ \\
$\mathrm{C}^{1} \mathrm{M}^{3} \mathrm{~L}$ & $0.2319(6.1311)$ \\
$\mathrm{M}^{2} \mathrm{~L}$ & -54.7709 \\
Constant & \\
\hline
\end{tabular}

Table $6 \mathrm{~b}$

\begin{tabular}{lc} 
Character & Function 1 \\
\hline D3P2 & $1.0514(1.3822)$ \\
D3P1 & $-0.4575(-1.1849)$ \\
D5MC & $0.9814(1.4285)$ \\
M3MC & $-0.8619(-1.1053)$ \\
EL & $-0.3023(-0.7236)$ \\
Constant & -22.0157 \\
\hline
\end{tabular}

explains $67.6 \%$ of the variance, separated most of the populations in the Inner Banda Arc group of islands from the populations in the Outer Banda Arc islands (Figure 7a). Plots of combinations of other functions do not noticeably clarify further these groupings.

A DFA based on the two subgroups identified above, namely the Inner Banda Arc subgroup (Java, Madura, Lombok, Sumbawa, Moyo, Alor) and the Outer Banda Arc subgroup (Timor, Roti, Semau, Savu, Wetar and Selaru) and using a subset of five characters (see Table 6a) extracted a significant function (Figure 8a) which classified $91.2 \%$ of individuals to their correct population subgroup. A total of $93.8 \%$ and $88.7 \%$ of individuals in the Outer Banda Arc and Inner Banda Arc subgroups, respectively, were correctly classified. Individuals that were misclassified in the Outer Banda Arc subgroup comprised the following numbers of individuals: Roti, 1; Semau, 1; and Savu, 2. Inner Banda Arc misclassifications were as follows: Java, 2; Moyo, 1; Sumbawa, 2; and Alor, 2. All characters had high coefficient values on Function 1 (Table 6a).

External characters - a DFA based on all populations in the Savu Group and using a subset of five characters (digit 3 phalanx 2, tibia length, ear length, forearm length and digit 3 metacarpal length) extracted three significant functions, which combined explained $95.6 \%$ of the variance. There was considerable overlap between these populations with only $57.6 \%$ of individuals classified to their correct populations. Plots of Functions 1 and 2 (Figure $7 \mathrm{~b}$ ) revealed most of the separation between these populations, which 


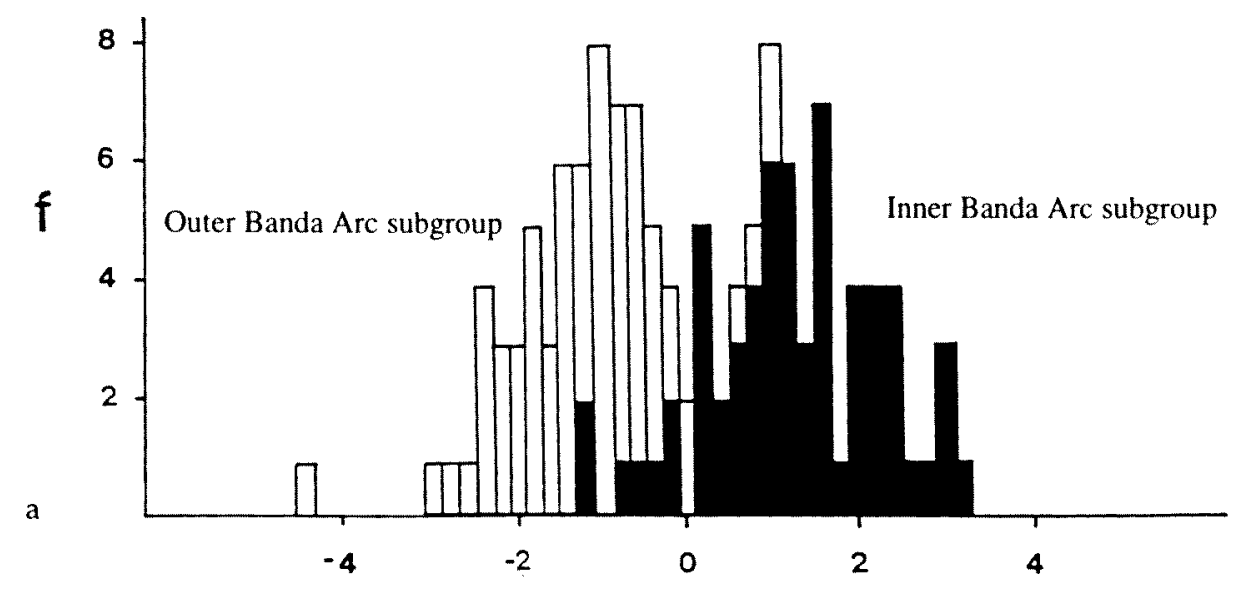

Function 1

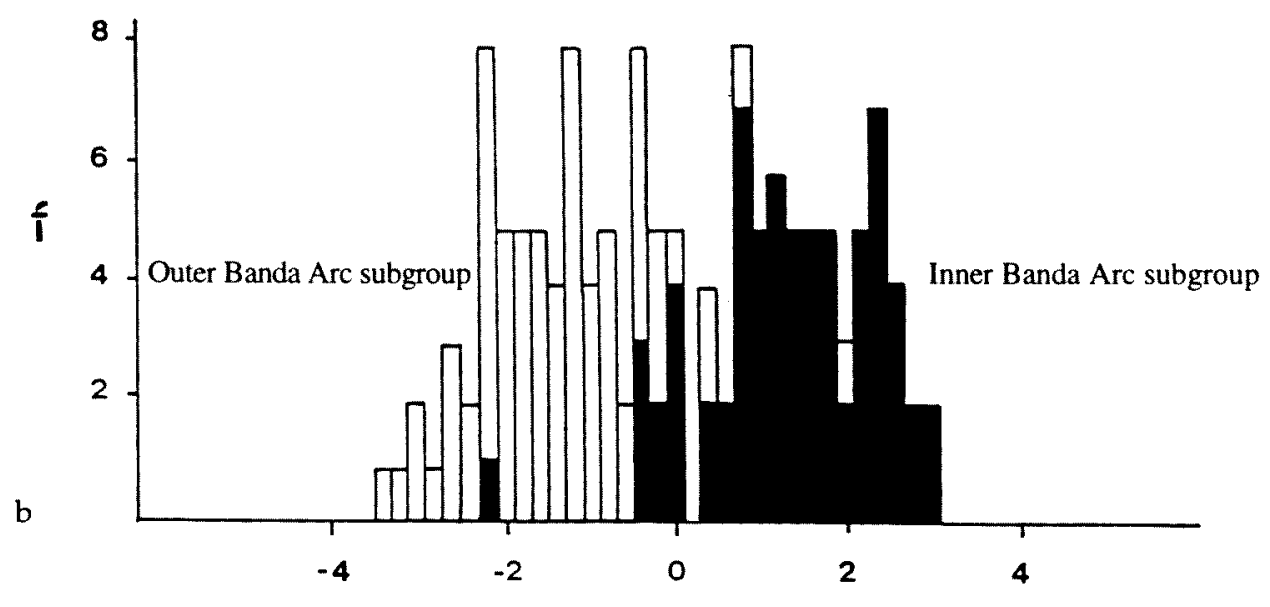

Function 1

Figure 8 Plot of DFA Functions 1 and 2 based on five (a) skull and (b) external body characters and two groupings (Inner and Outer Banda Arc, with Wetar island placed in the Outer Banda Arc subgroup) (see text) for adult Miniopterus. Locality codes as for Figure 2.

cluster similarly to the populations that were clustered above based on skull characters.

A DFA based on the Inner and Outer Banda Arc subgroups above and using a subset of five external body characters (see Table 6b) extracted a significant function (Figure $8 \mathrm{~b}$ ) which classified $92.7 \%$ of individuals to their correct population subgroup. A total of $94.1 \%$ and $91.3 \%$ of individuals in the Outer Banda Arc and Inner Banda Arc subgroup, respectively, were classified correctly. Numbers of individuals that were misclassified in the Outer Banda Arc subgroup comprised the following: Semau, 1; Roti, 1; Savu, 1; and Timor, 1. The characters that had high coefficient values $(>0.5)$ were digit 3 phalanx 2 length, and both digit 3 and digit 5 metacarpal lengths (Table $6 b$ ).

\section{Summary of multivariate analysis}

The combination of DFA on skull and external body measurements of specimens of Miniopterus used in this study indicated the presence of considerable morphological differentiation among these island populations. Four distinct groups of populations were identified (Java, New Guinea, Selaru and Savu). The Java Group was the most distinctive and was separated from these other population groups, both in skull and external body characters, but particularly the latter. The Savu Group was separated from the remaining three populations groups on skull characters but could not be separated from the Selaru Group on external body characters. The New Guinea and Selaru Groups were separated principally on external body characters.

All four population groups are recognised as separate species. Within each of these four major population groups there was morphological differentiation, some of which is recognised as 
being subspecifically distinct. Named taxa relate to the population groups and subgroups as follows:

Java Group: Miniopterus pusillus

Western subgroup: M.p. pusillus

Southeastern subgroup: $M$. pusillus subsp. indet. A

Seram subgroup: $M$. p. subsp. indet. cf. M. pusillus subsp. indet. A.

New Guinea Group: Miniopterus australis

Papua New Guinea/Queensland/NSW subgroup: M. a. tibialis

Seram unallocated: $M$. a. tibialis

Kai subgroup: M. a. subsp. indet.

Selaru Group: Miniopterus paululus

Philippines subgroup: M. p. paululus

Borneo subgroup: M. p. witkampi

Selaru subgroup: $M . p$. subsp. nov.

\section{Savu Group: Miniopterus shortridgei}

Inner Banda Arc subgroup: M. s. shortridgei

Outer Banda Arc subgroup: $M$. s. subsp. indet.

The following systematic section describes these above taxa using univariate analyses, particularly measurements of means and ranges of characters, but also of bivariate plots of characters that were indicated by DFA to be important. These important characters were recognised as those with high standardised canonical discriminant function coefficients (presented in text) as well those with high loadings (from the pooled- within-groups correlations between discriminating variables and canonical discriminant functions).

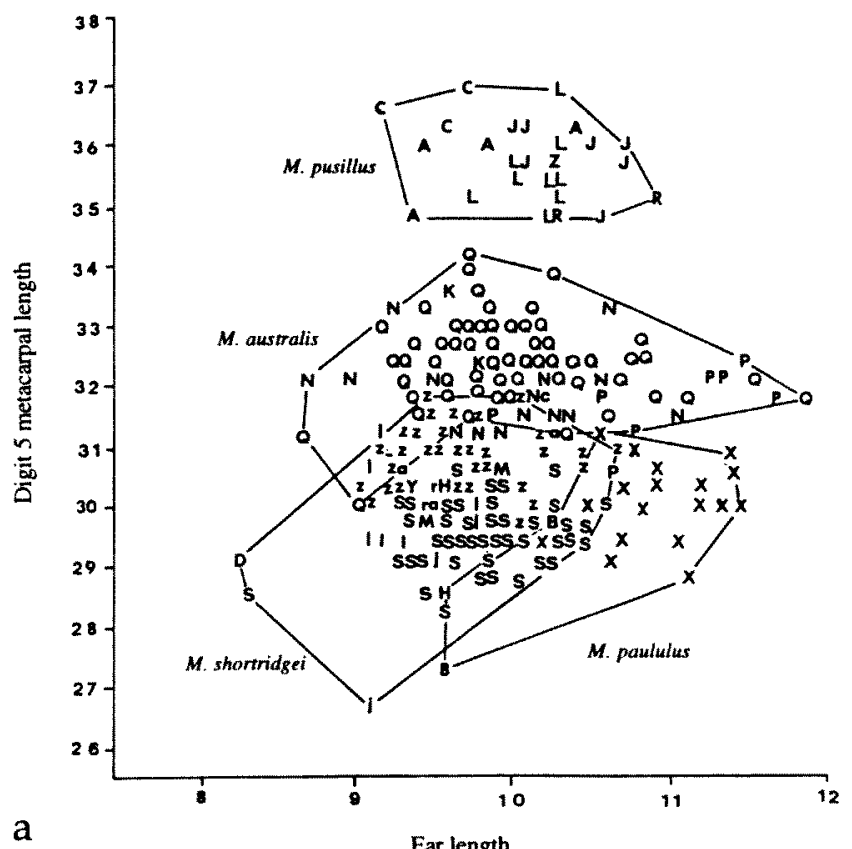

\section{TAXONOMY}

\section{Miniopterus pusillus Dobson, 1876}

M. pusillus Dobson, 1876: 162

M. macrocneme Revilliod, 1914: 360

Lectotype: Wroughton (1918:22) designated specimen number 185, Indian Museum, collected by Stoliczka, as the lectotype.

Type locality: Nicobar islands (see Wroughton 1918:22)

Type locality not listed in Dobson (1876) but he lists specimens (p. 163) of M. pusillus collected from Nicobar islands and Madras (apparently by Stoliczka - see Dobson, 1871). Hill (1983) discussed both the choice of lectotype and the type locality (Nicobar islands) by Wroughton (1918) and agrees with him. It appears that both Tate (1941) and Ellerman and Morrison-Scott (1951) were incorrect in selecting a lectotype from Madras.

\section{Diagnosis}

Miniopterus pusillus differs from $M$. australis, $M$. paululus and $M$. shortridgei by averaging larger in most external body characters (Table $7 \mathrm{~b}$ ) and with digit 5 metacarpal longer relative to ear length (Figure 9a).

It differs from $M$. australis in being on average larger in all external body characters; for example, in having both a generally longer forearm length $42.6(36.5-44.3) 35$ v. $39.2(37.4-41.6) 107$ and tibia

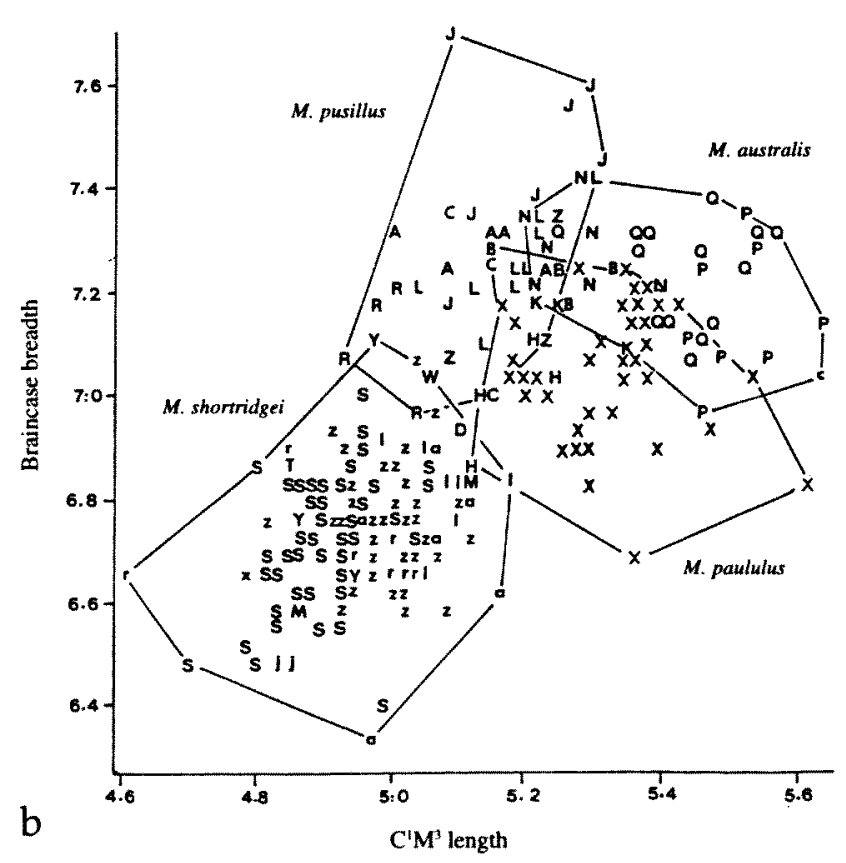

Figure 9 Plot of (a) digit 5 metacarpal length ( $\mathrm{mm}$ ) versus ear length (mm) and (b) braincase breadth (mm) versus $\mathrm{C}^{1} \mathrm{M}^{3}$ length ( $\mathrm{mm}$ ) for all populations of adult Miniopterus considered (pusillus, australis, paululus and shortridgei). Locality codes as for Figure 2. 
length $19.0(14.7-20.3) 35$ v. $15.9(14.8-17.3)$ 107. It also is on average smaller in all skull characters (Table 7a), except cranial height, least interorbital breadth and braincase breadth; for example, greatest skull length $13.5(12.9-14.0) 35 v .14 .0$ (13.514.4) 36 and $\mathrm{C}^{1} \mathrm{M}^{3}$ length 5.2 (4.9-5.3) 35 v. 5.4 (5.25.6) 36. Also upper molar row generally shorter relative to braincase breadth (Figure $9 \mathrm{~b}$ ).

It differs from $M$. paululus in being on average larger in all external body characters except ear length; for example, forearm length 14.0 (13.5-14.4) 36 v. 37.1 (34.2-38.7) 34 and tibia length 19.0 (14.720.2) 35 v. $15.0(13.9-15.6) 34$. Tail to vent length absolutely larger 44.8 (39.7-51.2) 34 v. 34.8 (31.239.0) 34. It is on average smaller in all skull characters, except mastoid width, cranial height, least interorbital breadth and braincase breadth (Table 7a). For example, greatest skull length 13.5 (12.9-14.0) 35 v. 13.8 (13.1-14.3) 53 and cranial height $5.8(5.6-6.3) 34$ v. $5.5(5.2-5.7)$ 53. Upper molar cusp row generally shorter relative to braincase breadth (Figure 9b).

It differs from $M$. shortridgei in averaging larger in all skull and external body characters. For example, forearm length $42.6(36.5-44.3) 35$ v. 36.8 (33.3-39.3) 148; tibia length $19.0(14.7-20.2) 35$ v. 15.0 (13.416.4) 150; greatest skull length 13.5 (12.9-14.0) $35 v$. 13.3 (12.6-13.8) 135; and $\mathrm{C}^{1} \mathrm{M}^{3}$ length 5.2 (4.9-5.3) 35 v. $5.0(4.6-5.2) 137$. Braincase breadth usually greater relative to upper molar cusp row length (Figure 9b).

\section{Miniopterus pusillus pusillus Dobson, 1876}

Lectotype and type locality: stated above.

Specimens examined: Indonesia; Java Island Cibeureum, $6^{\circ} 44^{\prime}$ S, $107^{\circ} 00^{\prime} \mathrm{E}$, WAM M(27160-4) 29 q $3 \delta^{\circ} \sigma^{\circ}$. Kiskenda, $7^{\circ} 06^{\prime} \mathrm{S}, 1^{\circ} 10^{\circ} 16^{\prime} \mathrm{E}, \mathrm{WAM} \mathrm{M}(39322$, 39327, 39371) 3 ơ ô. Lombok Island - Bang Kang, $8^{\circ} 30^{\prime} \mathrm{S}, 116^{\circ} 10^{\prime} \mathrm{E}$, WAM (M35850-54, 35857-8, 35868, $35873,35876,35960) 8 \% q, 3{ }^{\circ} \delta$. Sumbawa Island Batu Tering, $8^{\circ} 48^{\prime} \mathrm{S}, 117^{\circ} 22^{\prime} \mathrm{E}$, WAM M31453 $q$. Desa Sangeang, $8^{\circ} 18^{\prime} \mathrm{S}, 118^{\circ} 56^{\prime} \mathrm{E}$, WAM M(31547-8) $20^{\circ} 0^{\circ}$.

\section{Diagnosis}

Miniopterus $p$. pusillus differs from $M$. pusillus subsp. A (see below) by averaging larger in all external body and skull characters, except for digit 3 phalanx length, mesopterygoid fossa breadth and $\mathrm{M}^{2}$ breadth, which are subequal in length (Table 7a, b). For example, forearm length 42.8 (40.5 44.1) 21 v. 42.0 (36.5-44.3) 11; tibia length $19.2(18.2-20.2) 21$ v. $18.6(14.7-20.0) 11$; greatest skull length 13.6 (13.2-14.0) 22 v. 13.4 (12.9-13.8) 10; $\mathrm{M}^{3} \mathrm{M}^{3}$ distance $5.5(5.3-5.7) 22$ v. $5.3(5.1-5.5)$ 10. Ear generally longer relative to digit 3 phalanx 3 length (Figure $10)$.

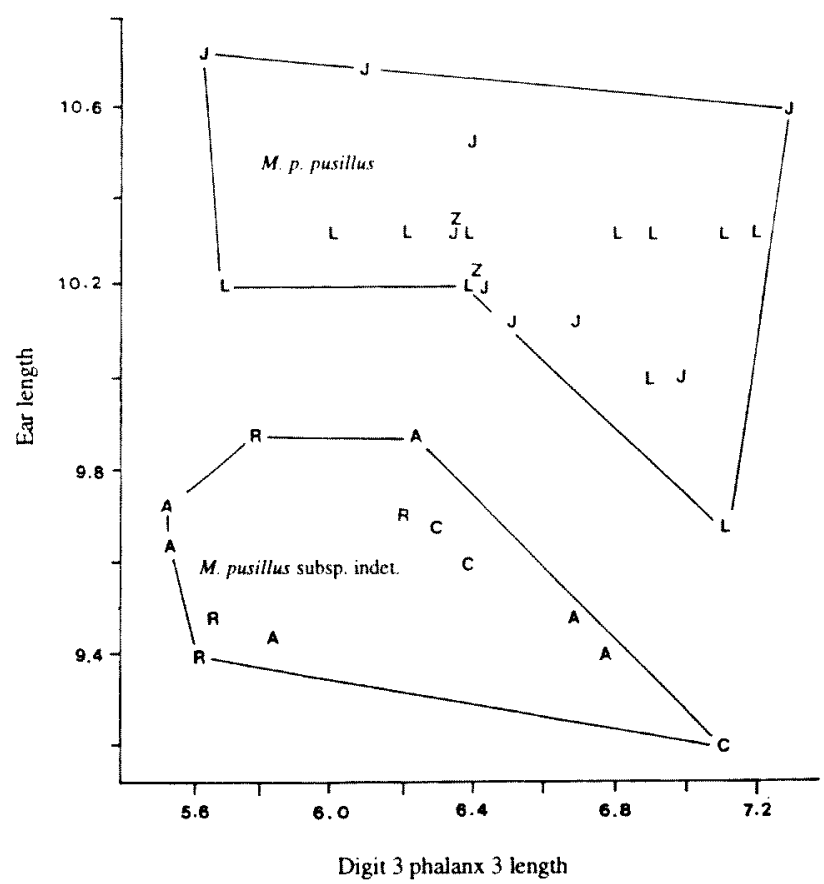

Figure 10 Plot of ear length $(\mathrm{mm})$ versus digit 3 phalanx 3 length (mm) for island populations of adult Miniopterus pusillus pusillus and M. $p$. macrocneme. Island codes as for Figure 2.

It differs from $M$. pusillus subsp. indet. cf. $M . p$. subsp. indet. A from Seram island by averaging smaller in most external body characters, and larger in most skull characters (Table $7 \mathrm{a}, 7 \mathrm{~b}$ ). For example, forearm length $42.8(40.5-44.1) 21$ v. 43.4 (42.9-43.7) 3 ; ear length 10.3 (9.7-10.7) 21 v. 9.5 (9.2-9.7) 3; greatest skull length 13.63 (13.16-14.02) 22 v. 13.35 (13.27-13.42) 3 and $C^{1} \mathrm{M}^{3}$ length 5.20 (5.04-5.32) 22 v. $5.13(5.08-5.15) 3$. Ear longer relative to digit 3 phalanx 3 length (Figure 10).

\section{Distribution}

Lombok, Sumbawa (this study); Nicobar Islands (type locality); Madras, Thailand, Hong Kong, Java and Sumatra (Hill 1983, Hill in Corbet and Hill 1992).

\section{Miniopterus pusillus subsp. indet. A}

Specimens examined: Indonesia; Alor Island Kalabahi, $8^{\circ} 14^{\prime} \mathrm{S}, 124^{\circ} 32^{\prime} \mathrm{E}$, WAM M(37567E, 37875, 37886E, 37904-7) 7 o $\delta$. Roti Island - Baa, $10^{\circ} 44^{\prime} \mathrm{S}$, $123^{\circ} 06^{\prime} \mathrm{E}$, WAM M(35357, 35359E, 35387S, $\left.123^{\circ} 06^{\prime} 35402,35404\right) 5 \% q$. Seram island Manusela, $3^{\circ} 10^{\prime} \mathrm{S}, 129^{\circ} 36^{\prime} \mathrm{E}$, WAM M(34719, 34724, 34726) $3 q$ ㅇ.

\section{Diagnosis}

Miniopterus pusillus subsp. indet. A and the referred specimen from Seram island differs from M. p. pusillus as described in the earlier diagnosis of that subspecies. 
Table 7 Measurements of adult (males and females combined) Miniopterus pusillus, $M$. australis, M. paululus and $M$. shortridgei and their subspecies and unnamed forms and population Group and subgroup names from this study (a) cranial, dentary and dental and (b) external body characters. 0 , mean; SD, standard deviation; MIN, minimum; MAX, maximum and N, sample size. Character codes defined in text.

\begin{tabular}{|c|c|c|c|c|c|c|c|c|c|c|c|c|c|c|c|c|c|c|}
\hline & & GSL & BCL & PL & ICD & MW & MFB & $\mathrm{CH}$ & LIB & ZW & BB & $\mathbf{C}^{1} \mathbf{M}^{3}$ & $C^{1} C^{1}$ & $\mathbf{M}^{3} \mathbf{M}^{3}$ & $\mathbf{M}^{2} \mathbf{L}$ & $\mathbf{M}^{2} \mathbf{B}$ & $\mathbf{I}^{1} \mathbf{M}^{\mathbf{3}}$ & DL \\
\hline $\begin{array}{l}\text { Miniopterus pusillus } \\
\text { (Java Group) }\end{array}$ & $\begin{array}{c}\overline{\mathbf{x}} \\
\text { SD } \\
\text { MIN } \\
\text { MAX } \\
\text { N } \\
\end{array}$ & $\begin{array}{c}13.53 \\
0.27 \\
12.92 \\
14.02 \\
35 \\
\end{array}$ & $\begin{array}{c}5.18 \\
0.16 \\
4.85 \\
5.46 \\
31 \\
\end{array}$ & $\begin{array}{c}5.16 \\
0.16 \\
4.72 \\
5.43 \\
33 \\
\end{array}$ & $\begin{array}{c}1.23 \\
0.06 \\
1.11 \\
1.38 \\
34 \\
\end{array}$ & $\begin{array}{c}7.64 \\
0.20 \\
7.00 \\
8.07 \\
35 \\
\end{array}$ & $\begin{array}{c}1.68 \\
0.14 \\
1.39 \\
1.94 \\
29 \\
\end{array}$ & $\begin{array}{c}5.83 \\
0.16 \\
5.55 \\
6.25 \\
34 \\
\end{array}$ & $\begin{array}{c}3.48 \\
0.11 \\
3.23 \\
3.68 \\
35 \\
\end{array}$ & $\begin{array}{c}7.48 \\
0.21 \\
6.83 \\
7.88 \\
30 \\
\end{array}$ & $\begin{array}{c}7.27 \\
0.16 \\
6.96 \\
7.71 \\
35 \\
\end{array}$ & $\begin{array}{c}5.16 \\
0.10 \\
4.93 \\
5.32 \\
35 \\
\end{array}$ & $\begin{array}{c}3.93 \\
0.14 \\
3.57 \\
4.12 \\
35 \\
\end{array}$ & $\begin{array}{c}5.44 \\
0.13 \\
5.09 \\
5.69 \\
35 \\
\end{array}$ & $\begin{array}{c}1.21 \\
0.04 \\
1.12 \\
1.29 \\
35\end{array}$ & $\begin{array}{c}1.40 \\
0.06 \\
1.29 \\
1.56 \\
35\end{array}$ & $\begin{array}{c}6.55 \\
0.12 \\
6.30 \\
6.86 \\
33\end{array}$ & $\begin{array}{c}9.59 \\
0.19 \\
9.25 \\
10.04 \\
35\end{array}$ \\
\hline $\begin{array}{l}\text { M.p. pusillus } \\
\text { (Western subgroup) }\end{array}$ & $\begin{array}{c}\bar{x} \\
\text { SD } \\
\text { MIN } \\
\text { MAX } \\
\text { N }\end{array}$ & $\begin{array}{c}13.63 \\
0.25 \\
13.16 \\
14.02 \\
22 \\
\end{array}$ & $\begin{array}{c}5.21 \\
0.15 \\
5.01 \\
5.46 \\
21 \\
\end{array}$ & $\begin{array}{c}5.19 \\
0.14 \\
4.99 \\
5.43 \\
22 \\
\end{array}$ & $\begin{array}{c}1.24 \\
0.07 \\
1.11 \\
1.38 \\
22 \\
\end{array}$ & $\begin{array}{c}7.72 \\
0.16 \\
7.29 \\
8.07 \\
22 \\
\end{array}$ & $\begin{array}{c}1.66 \\
0.15 \\
1.39 \\
1.94 \\
19 \\
\end{array}$ & $\begin{array}{c}5.88 \\
0.16 \\
5.62 \\
6.25 \\
22 \\
\end{array}$ & $\begin{array}{c}3.51 \\
0.11 \\
3.23 \\
3.68 \\
22 \\
\end{array}$ & $\begin{array}{c}7.57 \\
0.16 \\
7.22 \\
7.88 \\
17 \\
\end{array}$ & $\begin{array}{c}7.31 \\
0.17 \\
7.07 \\
7.71 \\
22 \\
\end{array}$ & $\begin{array}{c}5.20 \\
0.08 \\
5.04 \\
5.32 \\
22 \\
\end{array}$ & $\begin{array}{c}3.98 \\
0.12 \\
3.64 \\
4.12 \\
22 \\
\end{array}$ & $\begin{array}{c}5.49 \\
0.10 \\
5.28 \\
5.69 \\
22 \\
\end{array}$ & $\begin{array}{c}1.22 \\
0.04 \\
1.17 \\
1.29 \\
22 \\
\end{array}$ & $\begin{array}{c}1.41 \\
0.07 \\
1.29 \\
1.56 \\
22 \\
\end{array}$ & $\begin{array}{c}6.60 \\
0.10 \\
6.41 \\
6.86 \\
20 \\
\end{array}$ & $\begin{array}{c}9.65 \\
0.18 \\
9.34 \\
10.04 \\
22 \\
\end{array}$ \\
\hline $\begin{array}{l}\text { M. pusillus subsp. indet A } \\
\text { (Southeastern subgroup) }\end{array}$ & $\begin{array}{c}\bar{x} \\
\text { SD } \\
\text { MIN } \\
\text { MAX } \\
\text { N }\end{array}$ & $\begin{array}{c}13.36 \\
0.24 \\
12.92 \\
13.79 \\
10\end{array}$ & $\begin{array}{c}5.08 \\
0.20 \\
4.85 \\
5.38 \\
7\end{array}$ & $\begin{array}{c}5.08 \\
0.21 \\
4.72 \\
5.35 \\
8\end{array}$ & $\begin{array}{c}1.22 \\
0.04 \\
1.17 \\
1.31 \\
9\end{array}$ & $\begin{array}{c}7.49 \\
0.21 \\
7.00 \\
7.77 \\
10\end{array}$ & $\begin{array}{c}1.73 \\
0.09 \\
1.58 \\
1.84 \\
7\end{array}$ & $\begin{array}{c}5.71 \\
0.11 \\
5.55 \\
5.92 \\
9 \\
\end{array}$ & $\begin{array}{c}3.43 \\
0.10 \\
3.32 \\
3.58 \\
10\end{array}$ & $\begin{array}{c}7.32 \\
0.24 \\
6.83 \\
7.56 \\
10 \\
\end{array}$ & $\begin{array}{c}7.20 \\
0.12 \\
6.96 \\
7.33 \\
10 \\
\end{array}$ & $\begin{array}{c}5.08 \\
0.10 \\
4.93 \\
5.23 \\
10 \\
\end{array}$ & $\begin{array}{c}3.83 \\
0.14 \\
3.57 \\
3.98 \\
10 \\
\end{array}$ & $\begin{array}{c}5.34 \\
0.13 \\
5.09 \\
5.50 \\
10 \\
\end{array}$ & $\begin{array}{c}1.18 \\
0.04 \\
1.12 \\
1.27 \\
10 \\
\end{array}$ & $\begin{array}{c}1.38 \\
0.05 \\
1.29 \\
1.43 \\
10 \\
\end{array}$ & $\begin{array}{c}6.49 \\
0.12 \\
6.30 \\
6.62 \\
10 \\
\end{array}$ & $\begin{array}{c}9.53 \\
0.19 \\
9.25 \\
9.76 \\
10\end{array}$ \\
\hline $\begin{array}{l}\text { M. pusillus subsp. indet A } \\
\text { (Seram subgroup) }\end{array}$ & $\begin{array}{c}\overline{\mathbf{x}} \\
\text { SD } \\
\text { MIN } \\
\text { MAX } \\
\text { N }\end{array}$ & $\begin{array}{c}13.35 \\
0.08 \\
13.27 \\
13.42 \\
3 \\
\end{array}$ & $\begin{array}{c}5.21 \\
0.01 \\
5.20 \\
5.22 \\
3 \\
\end{array}$ & $\begin{array}{c}5.08 \\
0.08 \\
4.99 \\
5.14 \\
3 \\
\end{array}$ & $\begin{array}{c}1.20 \\
0.07 \\
1.12 \\
1.26 \\
3 \\
\end{array}$ & $\begin{array}{c}7.60 \\
0.06 \\
7.55 \\
7.66 \\
3 \\
\end{array}$ & $\begin{array}{c}1.66 \\
0.08 \\
1.60 \\
1.75 \\
3 \\
\end{array}$ & $\begin{array}{c}5.82 \\
0.11 \\
5.69 \\
5.90 \\
3 \\
\end{array}$ & $\begin{array}{c}3.44 \\
0.02 \\
3.42 \\
3.46 \\
3 \\
\end{array}$ & $\begin{array}{c}7.48 \\
0.10 \\
7.37 \\
7.54 \\
3 \\
\end{array}$ & $\begin{array}{c}7.19 \\
0.18 \\
6.99 \\
7.34 \\
3 \\
\end{array}$ & $\begin{array}{c}5.13 \\
0.04 \\
5.08 \\
5.15 \\
3 \\
\end{array}$ & $\begin{array}{c}3.89 \\
0.08 \\
3.81 \\
3.96 \\
3 \\
\end{array}$ & $\begin{array}{c}5.43 \\
0.10 \\
5.32 \\
5.49 \\
3 \\
\end{array}$ & $\begin{array}{c}1.17 \\
0.03 \\
1.15 \\
1.20 \\
3 \\
\end{array}$ & $\begin{array}{c}1.42 \\
0.08 \\
1.40 \\
1.45 \\
3 \\
\end{array}$ & $\begin{array}{c}6.50 \\
0.08 \\
6.41 \\
6.55 \\
3 \\
\end{array}$ & $\begin{array}{c}9.43 \\
0.08 \\
9.34 \\
9.48 \\
3 \\
\end{array}$ \\
\hline $\begin{array}{l}\text { M. australis } \\
\text { (New Guinea Group) }\end{array}$ & $\begin{array}{c}\overline{\mathbf{x}} \\
\text { SD } \\
\text { MIN } \\
\text { MAX } \\
\text { N }\end{array}$ & $\begin{array}{c}14.00 \\
0.19 \\
13.48 \\
14.44 \\
36 \\
\end{array}$ & $\begin{array}{c}5.28 \\
0.11 \\
5.00 \\
5.46 \\
33 \\
\end{array}$ & $\begin{array}{c}5.40 \\
0.14 \\
5.08 \\
5.74 \\
33 \\
\end{array}$ & $\begin{array}{c}1.24 \\
0.08 \\
1.08 \\
1.39 \\
35 \\
\end{array}$ & $\begin{array}{c}7.72 \\
0.18 \\
7.03 \\
8.02 \\
36 \\
\end{array}$ & $\begin{array}{c}1.75 \\
0.07 \\
1.61 \\
1.87 \\
30 \\
\end{array}$ & $\begin{array}{c}5.76 \\
0.13 \\
5.47 \\
6.02 \\
36 \\
\end{array}$ & $\begin{array}{c}3.42 \\
0.08 \\
3.30 \\
3.60 \\
36 \\
\end{array}$ & $\begin{array}{c}7.59 \\
0.16 \\
7.20 \\
7.91 \\
31 \\
\end{array}$ & $\begin{array}{c}7.21 \\
0.11 \\
6.96 \\
7.41 \\
36 \\
\end{array}$ & $\begin{array}{c}5.40 \\
0.12 \\
5.20 \\
5.63 \\
36 \\
\end{array}$ & $\begin{array}{c}3.99 \\
0.10 \\
3.84 \\
4.27 \\
36 \\
\end{array}$ & $\begin{array}{c}5.67 \\
0.14 \\
5.34 \\
5.98 \\
35 \\
\end{array}$ & $\begin{array}{c}1.30 \\
0.04 \\
1.21 \\
1.38 \\
36\end{array}$ & $\begin{array}{c}1.48 \\
0.06 \\
1.33 \\
1.56 \\
36\end{array}$ & $\begin{array}{c}6.80 \\
0.15 \\
6.57 \\
7.12 \\
36\end{array}$ & $\begin{array}{c}10.00 \\
0.20 \\
9.67 \\
10.38 \\
36\end{array}$ \\
\hline $\begin{array}{l}\text { M. a. tibialis } \\
\text { (P.N.G. subgroup) }\end{array}$ & $\begin{array}{c}\bar{x} \\
\text { SD } \\
\text { MIN } \\
\text { MAX } \\
\text { N }\end{array}$ & $\begin{array}{c}14.05 \\
0.12 \\
13.94 \\
14.21 \\
8\end{array}$ & $\begin{array}{c}5.31 \\
0.06 \\
5.24 \\
5.38 \\
7\end{array}$ & $\begin{array}{c}5.51 \\
0.12 \\
5.36 \\
5.74 \\
7\end{array}$ & $\begin{array}{c}1.26 \\
0.07 \\
1.16 \\
1.33 \\
7\end{array}$ & $\begin{array}{c}7.62 \\
0.25 \\
7.03 \\
7.86 \\
8\end{array}$ & $\begin{array}{c}1.80 \\
0.04 \\
1.75 \\
1.87 \\
6\end{array}$ & $\begin{array}{c}5.77 \\
0.14 \\
5.47 \\
5.90 \\
8 \\
\end{array}$ & $\begin{array}{c}3.43 \\
0.09 \\
3.32 \\
3.60 \\
8 \\
\end{array}$ & $\begin{array}{c}7.57 \\
0.17 \\
7.30 \\
7.82 \\
8 \\
\end{array}$ & $\begin{array}{c}7.15 \\
0.13 \\
6.96 \\
7.34 \\
8 \\
\end{array}$ & $\begin{array}{c}5.51 \\
0.06 \\
5.44 \\
5.63 \\
8 \\
\end{array}$ & $\begin{array}{c}4.02 \\
0.09 \\
3.90 \\
4.14 \\
8 \\
\end{array}$ & $\begin{array}{c}5.78 \\
0.10 \\
5.65 \\
5.98 \\
8 \\
\end{array}$ & $\begin{array}{c}1.30 \\
0.02 \\
1.27 \\
1.33 \\
8 \\
\end{array}$ & $\begin{array}{c}1.50 \\
0.02 \\
1.47 \\
1.53 \\
8 \\
\end{array}$ & $\begin{array}{c}6.93 \\
0.06 \\
6.85 \\
7.00 \\
8 \\
\end{array}$ & $\begin{array}{c}10.16 \\
0.11 \\
9.99 \\
10.31 \\
8 \\
\end{array}$ \\
\hline $\begin{array}{l}\text { M. a. tibialis } \\
\text { (Queensland/NSW } \\
\text { subgroup) }\end{array}$ & $\begin{array}{c}\bar{x} \\
\text { SD } \\
\text { MIN } \\
\text { MAX } \\
\text { N }\end{array}$ & $\begin{array}{c}14.03 \\
0.17 \\
13.73 \\
14.44 \\
24 \\
\end{array}$ & $\begin{array}{c}5.28 \\
0.11 \\
5.00 \\
5.46 \\
22 \\
\end{array}$ & $\begin{array}{c}5.37 \\
0.13 \\
5.08 \\
5.57 \\
22 \\
\end{array}$ & $\begin{array}{c}1.25 \\
0.08 \\
1.10 \\
1.39 \\
24\end{array}$ & $\begin{array}{c}7.78 \\
0.13 \\
7.53 \\
8.02 \\
24 \\
\end{array}$ & $\begin{array}{c}1.74 \\
0.08 \\
1.61 \\
1.87 \\
20 \\
\end{array}$ & $\begin{array}{c}5.76 \\
0.14 \\
5.48 \\
6.02 \\
24 \\
\end{array}$ & $\begin{array}{c}3.41 \\
0.08 \\
3.30 \\
3.57 \\
24 \\
\end{array}$ & $\begin{array}{c}7.60 \\
0.17 \\
7.20 \\
7.91 \\
20 \\
\end{array}$ & $\begin{array}{c}7.25 \\
0.09 \\
7.06 \\
7.41 \\
24 \\
\end{array}$ & $\begin{array}{c}5.37 \\
0.11 \\
5.20 \\
5.56 \\
24 \\
\end{array}$ & $\begin{array}{c}3.98 \\
0.11 \\
3.84 \\
4.27 \\
24 \\
\end{array}$ & $\begin{array}{c}5.63 \\
0.14 \\
5.34 \\
5.91 \\
23 \\
\end{array}$ & $\begin{array}{c}1.29 \\
0.04 \\
1.21 \\
1.38 \\
24\end{array}$ & $\begin{array}{c}1.48 \\
0.05 \\
1.36 \\
1.56 \\
24\end{array}$ & $\begin{array}{c}6.77 \\
0.14 \\
6.57 \\
7.09 \\
24\end{array}$ & $\begin{array}{c}9.97 \\
0.20 \\
9.67 \\
10.38 \\
24\end{array}$ \\
\hline
\end{tabular}




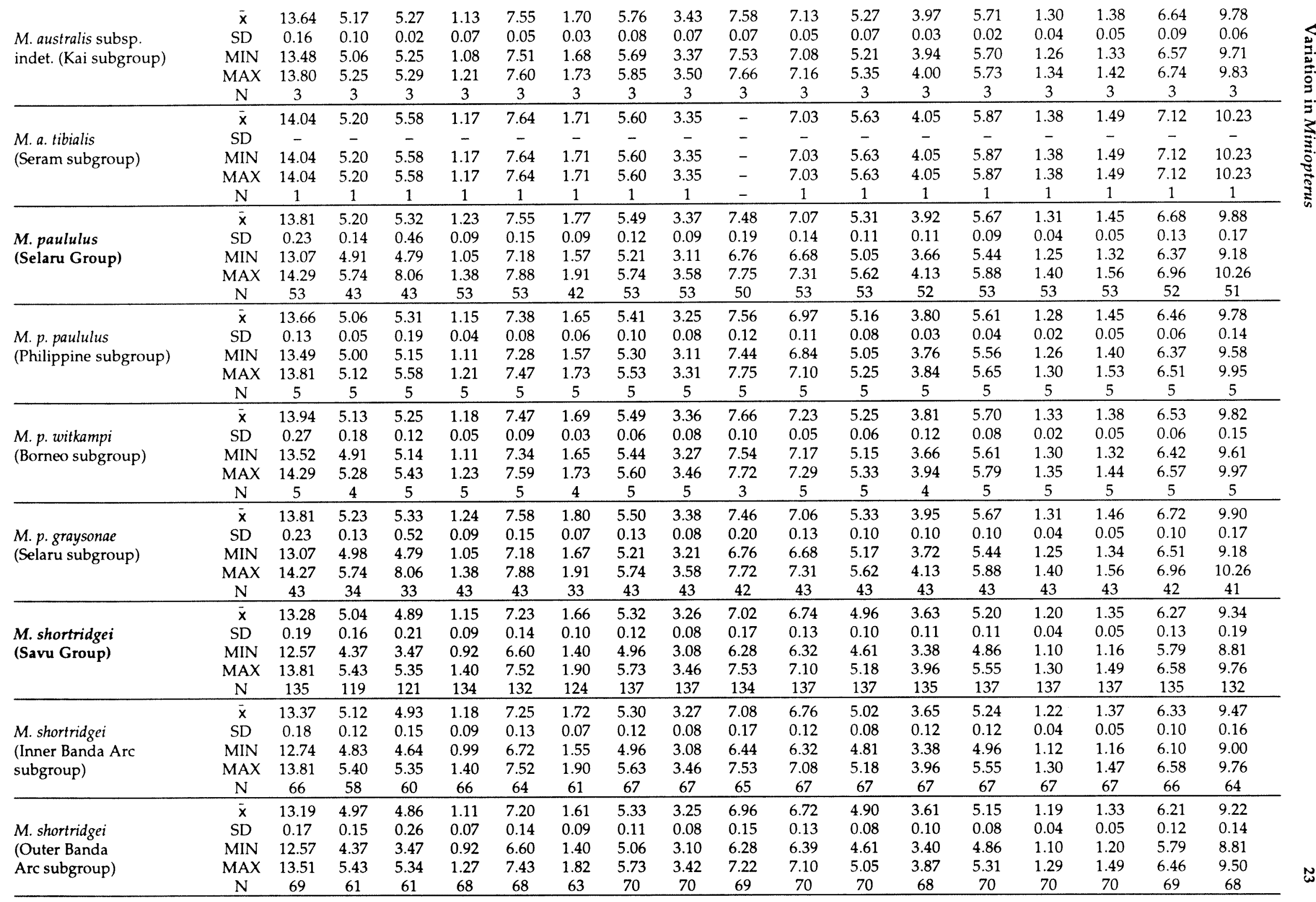


Table $7 \mathrm{~b}$ - Externals

SVL

TV EL

TIB

FA

D2MC

D3MC

D3P1

\begin{tabular}{cc} 
D3P2 & D \\
\hline 28.5 & 6 \\
1.3 & 0.5 \\
25.3 & 5.5
\end{tabular}

Miniopterus pusillus (Java Group)

$\begin{array}{cccc}\bar{x} & 44.5 & 44.8 & 10.1 \\ \text { SD } & 2.6 & 3.0 & 0.4 \\ \text { MIN } & 38.4 & 39.7 & 9.2 \\ \text { MAX } & 50.2 & 51.2 & 10.9 \\ \text { N } & 34 & 34 & 34\end{array}$

M. p.pusillus

MIN
MAX
$N$

34

(Western subgroup)

$\begin{array}{cc}\mathrm{X} & 45.4 \\ \mathrm{MD} & 2.3 \\ \mathrm{MAX} & 41.4 \\ \mathrm{~N} & 50.2\end{array}$

\begin{tabular}{|c|c|c|c|c|c|c|c|c|c|c|c|c|c|}
\hline & $\begin{array}{c}\text { MAX } \\
\mathrm{N}\end{array}$ & $\begin{array}{c}50.2 \\
20 \\
\end{array}$ & $\begin{array}{c}51.2 \\
21 \\
\end{array}$ & $\begin{array}{c}10.7 \\
21 \\
\end{array}$ & $\begin{array}{c}20.2 \\
21 \\
\end{array}$ & $\begin{array}{c}44.1 \\
21 \\
\end{array}$ & $\begin{array}{c}41.1 \\
21 \\
\end{array}$ & $\begin{array}{c}40.7 \\
21 \\
\end{array}$ & $\begin{array}{c}1.1 \\
21 \\
\end{array}$ & $\begin{array}{c}31.3 \\
21 \\
\end{array}$ & $\begin{array}{l}7.3 \\
21 \\
\end{array}$ & $\begin{array}{c}39.3 \\
21 \\
\end{array}$ & $\begin{array}{c}37.0 \\
21 \\
\end{array}$ \\
\hline $\begin{array}{l}\text { M. pusillus subsp. indet A } \\
\text { Southeastern subgroup) }\end{array}$ & $\begin{array}{c}\vec{x} \\
\text { SD } \\
\text { MIN } \\
\text { MAX } \\
\text { N }\end{array}$ & $\begin{array}{c}43.3 \\
2.2 \\
38.6 \\
46.5 \\
11 \\
\end{array}$ & $\begin{array}{c}43.9 \\
3.0 \\
40.1 \\
50.3 \\
11 \\
\end{array}$ & $\begin{array}{l}9.6 \\
0.2 \\
9.4 \\
9.9 \\
10 \\
\end{array}$ & $\begin{array}{c}18.6 \\
1.5 \\
14.7 \\
20.0 \\
11 \\
\end{array}$ & $\begin{array}{c}42.0 \\
2.2 \\
36.5 \\
44.3 \\
11 \\
\end{array}$ & $\begin{array}{c}38.1 \\
1.8 \\
33.9 \\
39.8 \\
11 \\
\end{array}$ & $\begin{array}{c}38.5 \\
1.9 \\
33.8 \\
40.2 \\
11 \\
\end{array}$ & $\begin{array}{c}10.2 \\
0.5 \\
9.1 \\
11.2 \\
11 \\
\end{array}$ & $\begin{array}{c}28.0 \\
1.7 \\
25.3 \\
30.2 \\
11 \\
\end{array}$ & $\begin{array}{l}6.1 \\
0.5 \\
5.5 \\
7.0 \\
11 \\
\end{array}$ & $\begin{array}{c}36.9 \\
1.8 \\
32.6 \\
38.7 \\
11 \\
\end{array}$ & $\begin{array}{c}34.4 \\
1.8 \\
30.1 \\
36.3 \\
11 \\
\end{array}$ \\
\hline $\begin{array}{l}\text { M. pusillus subsp. indet A } \\
\text { (Seram subgroup) }\end{array}$ & $\begin{array}{c}\bar{x} \\
\text { SD } \\
\text { MIN } \\
\text { MAX } \\
\text { N }\end{array}$ & $\begin{array}{c}42.7 \\
4.0 \\
38.4 \\
46.2 \\
3 \\
\end{array}$ & $\begin{array}{c}45.7 \\
4.3 \\
42.6 \\
48.7 \\
2 \\
\end{array}$ & $\begin{array}{c}9.5 \\
0.3 \\
9.2 \\
9.7 \\
3 \\
\end{array}$ & $\begin{array}{c}19.0 \\
0.7 \\
18.4 \\
19.7 \\
3 \\
\end{array}$ & $\begin{array}{c}43.4 \\
0.5 \\
42.9 \\
43.7 \\
3 \\
\end{array}$ & $\begin{array}{c}39.4 \\
1.0 \\
38.3 \\
40.1 \\
3 \\
\end{array}$ & $\begin{array}{c}40.3 \\
1.0 \\
39.2 \\
41.1 \\
3 \\
\end{array}$ & $\begin{array}{c}9.8 \\
0.3 \\
9.5 \\
10.1 \\
3 \\
\end{array}$ & $\begin{array}{c}29.3 \\
1.5 \\
27.6 \\
30.3 \\
3 \\
\end{array}$ & $\begin{array}{c}6.6 \\
0.4 \\
6.3 \\
7.1 \\
3 \\
\end{array}$ & $\begin{array}{c}38.7 \\
0.1 \\
38.6 \\
38.8 \\
3 \\
\end{array}$ & $\begin{array}{c}36.6 \\
0.4 \\
36.2 \\
37.0 \\
3 \\
\end{array}$ \\
\hline $\begin{array}{l}\text { M. australis } \\
\text { (New Guinea Group) }\end{array}$ & $\begin{array}{c}\overline{\mathbf{x}} \\
\text { SD } \\
\text { MIN } \\
\text { MAX } \\
\mathrm{N}\end{array}$ & $\begin{array}{c}43.1 \\
2.7 \\
33.9 \\
50.5 \\
89 \\
\end{array}$ & $\begin{array}{c}41.4 \\
3.5 \\
30.9 \\
48.9 \\
92 \\
\end{array}$ & $\begin{array}{c}10.1 \\
0.6 \\
8.7 \\
11.9 \\
105 \\
\end{array}$ & $\begin{array}{c}15.9 \\
0.5 \\
14.8 \\
17.3 \\
107 \\
\end{array}$ & $\begin{array}{c}39.2 \\
0.8 \\
37.4 \\
41.6 \\
107 \\
\end{array}$ & $\begin{array}{c}34.9 \\
0.9 \\
31.7 \\
37.1 \\
107 \\
\end{array}$ & $\begin{array}{c}35.6 \\
0.8 \\
32.8 \\
37.8 \\
107 \\
\end{array}$ & $\begin{array}{c}9.4 \\
0.4 \\
8.0 \\
10.9 \\
107 \\
\end{array}$ & $\begin{array}{c}25.3 \\
1.0 \\
21.7 \\
29.6 \\
107 \\
\end{array}$ & $\begin{array}{c}6.3 \\
0.6 \\
4.4 \\
7.5 \\
106 \\
\end{array}$ & $\begin{array}{c}34.4 \\
0.8 \\
31.9 \\
36.3 \\
107 \\
\end{array}$ & $\begin{array}{c}32.3 \\
0.7 \\
30.1 \\
34.1 \\
107 \\
\end{array}$ \\
\hline $\begin{array}{l}\text { M. a. tibialis } \\
\text { (P.N.G. subgroup) }\end{array}$ & $\begin{array}{c}\overline{\mathbf{x}} \\
\text { SD } \\
\text { MIN } \\
\text { MAX } \\
\mathrm{N} \\
\end{array}$ & $\begin{array}{c}44.7 \\
1.9 \\
41.5 \\
47.4 \\
10 \\
\end{array}$ & $\begin{array}{c}40.9 \\
3.2 \\
36.3 \\
46.3 \\
10 \\
\end{array}$ & $\begin{array}{c}10.7 \\
0.7 \\
9.7 \\
11.7 \\
10 \\
\end{array}$ & $\begin{array}{c}15.9 \\
0.4 \\
15.2 \\
16.5 \\
10 \\
\end{array}$ & $\begin{array}{c}39.7 \\
0.6 \\
38.8 \\
40.4 \\
10 \\
\end{array}$ & $\begin{array}{c}35.1 \\
0.7 \\
33.9 \\
36.4 \\
10 \\
\end{array}$ & $\begin{array}{c}35.8 \\
0.7 \\
34.4 \\
36.7 \\
10 \\
\end{array}$ & $\begin{array}{c}9.6 \\
0.3 \\
9.1 \\
10.2 \\
10 \\
\end{array}$ & $\begin{array}{c}25.9 \\
0.8 \\
24.2 \\
27.0 \\
10 \\
\end{array}$ & $\begin{array}{c}5.4 \\
0.4 \\
4.8 \\
6.2 \\
10 \\
\end{array}$ & $\begin{array}{c}34.0 \\
0.5 \\
33.1 \\
35.1 \\
10 \\
\end{array}$ & $\begin{array}{c}31.7 \\
0.6 \\
30.7 \\
32.3 \\
10 \\
\end{array}$ \\
\hline $\begin{array}{l}\text { M. australis tibialis } \\
\text { (Queensland/NSW } \\
\text { subgroup) }\end{array}$ & $\begin{array}{c}\bar{x} \\
\text { SD } \\
\text { MIN } \\
\text { MAX } \\
\text { N }\end{array}$ & $\begin{array}{c}42.9 \\
2.7 \\
33.9 \\
50.5 \\
75 \\
\end{array}$ & $\begin{array}{c}41.6 \\
3.6 \\
30.9 \\
48.9 \\
78 \\
\end{array}$ & $\begin{array}{c}10.0 \\
0.6 \\
8.7 \\
11.9 \\
91 \\
\end{array}$ & $\begin{array}{c}15.9 \\
0.4 \\
14.8 \\
16.9 \\
93 \\
\end{array}$ & $\begin{array}{c}39.1 \\
0.7 \\
37.4 \\
40.8 \\
93 \\
\end{array}$ & $\begin{array}{c}34.8 \\
0.9 \\
31.7 \\
36.6 \\
93 \\
\end{array}$ & $\begin{array}{c}35.5 \\
0.8 \\
32.8 \\
37.5 \\
93 \\
\end{array}$ & $\begin{array}{c}9.4 \\
0.4 \\
8.0 \\
10.9 \\
93 \\
\end{array}$ & $\begin{array}{c}25.2 \\
0.9 \\
21.7 \\
29.6 \\
93 \\
\end{array}$ & $\begin{array}{l}6.4 \\
0.5 \\
4.4 \\
7.5 \\
92 \\
\end{array}$ & $\begin{array}{c}34.1 \\
303 \\
3.6 \\
36.3 \\
93 \\
\end{array}$ & $\begin{array}{c}32.3 \\
0.7 \\
30.1 \\
34.1 \\
93 \\
\end{array}$ \\
\hline $\begin{array}{l}\text { M. australis subsp. indet. } \\
\text { (Kai subgroup) }\end{array}$ & $\begin{array}{c}\overline{\mathbf{x}} \\
\text { SD } \\
\text { MIN } \\
\text { MAX } \\
\text { N }\end{array}$ & $\begin{array}{c}43.2 \\
4.0 \\
40.3 \\
47.7 \\
3\end{array}$ & $\begin{array}{c}39.9 \\
0.4 \\
39.5 \\
40.2 \\
3\end{array}$ & $\begin{array}{c}9.8 \\
0.2 \\
9.6 \\
9.9 \\
3\end{array}$ & $\begin{array}{c}17.1 \\
0.2 \\
16.9 \\
17.3 \\
3 \\
\end{array}$ & $\begin{array}{c}41.1 \\
0.4 \\
40.8 \\
41.6 \\
3\end{array}$ & $\begin{array}{c}36.6 \\
0.4 \\
36.3 \\
37.1 \\
3\end{array}$ & $\begin{array}{c}37.5 \\
0.5 \\
37.0 \\
37.8 \\
3\end{array}$ & $\begin{array}{c}9.7 \\
0.3 \\
9.5 \\
10.0 \\
3 \\
\end{array}$ & $\begin{array}{c}26.1 \\
1.6 \\
24.3 \\
27.3 \\
3 \\
\end{array}$ & $\begin{array}{c}6.4 \\
0.1 \\
6.3 \\
6.5 \\
3\end{array}$ & $\begin{array}{c}35.6 \\
0.4 \\
35.2 \\
35.9 \\
3\end{array}$ & $\begin{array}{c}33.1 \\
0.7 \\
32.3 \\
33.7 \\
3\end{array}$ \\
\hline
\end{tabular}




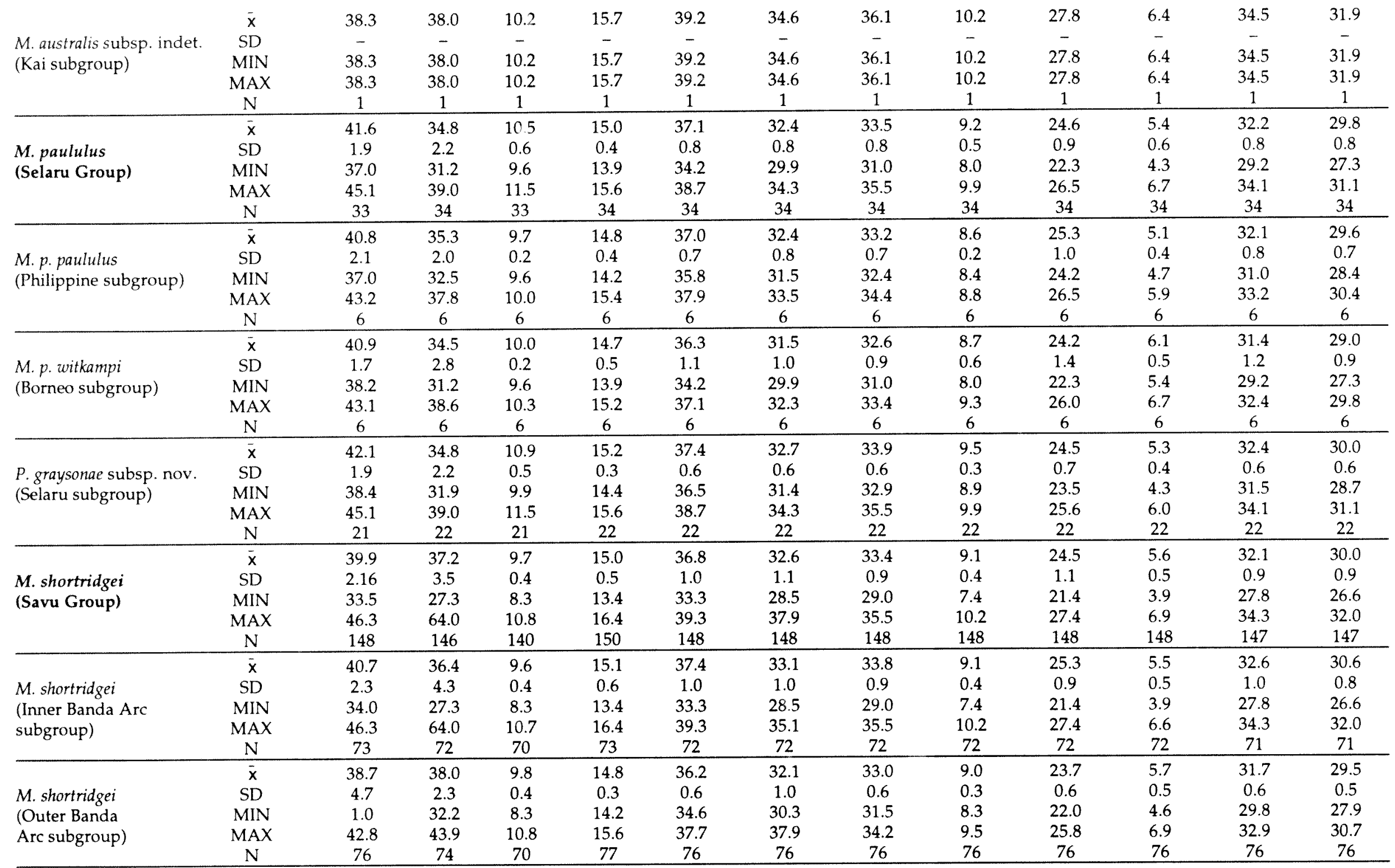




\section{Distribution}

Alor, Roti and probably Seram (this study) and Timor (Goodwin 1979), Ambon (Hill 1983) and possibly Sulawesi (Hill 1983).

\section{Referred specimens}

The three Seram specimens are morphologically slightly distinct from the Alor and Roti populations. However, because they are a small sample their subspecific status could not be assessed.

Remarks: Miniopterus pusillus from Ambon/Seram and Kai islands were thought by Maeda (1982) to represent the form pusillus, while Hill (1983) considered them macrocneme. Goodwin (1979) considered those from Timor island to be $M$. pusillus, whereas Hill (1983) placed them closer to macrocneme.

We tentatively ascribed specimens examined by us from Kai island to $M$. australis tibialis. These have measurements very similar to the $M$. pusillus reported by Hill (1983: Table 10) from that island.

Hill (1983) stated that M. p. macrocneme differed from $M$. p. pusillus by having longer tibia. In this study the Southeastern subgroup of $M$. pusillus, including specimens from Alor and Roti islands (close to Timor island) and the specimens from Seram (Seram subgroup) had tibia of a very similar length to those from the Western subgroup (Java, Lombok and Sumbawa) - that are M. p. pusillus.

Interestingly, the measurements listed by Hill (1983: Table 10) and Goodwin (1979) for M. pusillus specimens from Ambon/Seram islands and Timor island, respectively, fall within the range of measurements for the $M$. p. pusillus specimens in our Western subgroup, and are not clearly representative of the form macrocneme. Further, the difficulty in attributing specimens in the eastern Indonesian islands to macrocneme is further emphasised by the smaller cranial and dental measurements in our Table $7 a, b$ for the Southeastern subgroup (Roti, Alor islands) and those presented by Revilliod (1914) - in his description of $M$. macrocneme. For example, greatest skull length 13.6 (13.2-14.0) 22 v. 14.2 (14.0-14.4) 4; mastoid width $7.7(7.3-8.1) 22$ v. $8.1(8.0-8.2) 4 ; \mathrm{C}^{1} \mathrm{M}^{3}$ length $5.2(5.0-5.3) 22$ v. $5.6(5.5-5.8)$. Tibia length, for the Southeastern subgroup specimens, however, averaged larger than for $M$. macrocneme (s.s) 19.2 (18.2-20.2) 21 v. $18.3(17.8-19.0) 50$.

Specimens attributed by Hill (1983) to macrocneme from areas intermediate (Solomon and New Hebrides Islands, New Guinea) between New Caledonia/Loyalty islands and Alor, Roti, Timor and Seram appeared to indeed represent macrocneme. We have not examined specimens of macrocneme (s. s.) or sampled these 'intermediate' areas. However, we consider it probable that the forms in both the Seram and Southeastern subgroups will prove to be subspecifically distinct from both $M . p$. pusillus and $M . p$. macrocneme.

\section{Miniopterus australis Tomes, 1858}

\section{M. australis Tomes, 1858: 125}

\section{M. tibialis Tomes, 1858}

\section{?M. solomonensis Maeda, 1982}

Lectotype: British Museum, Natural History No. $\mathrm{BM}(\mathrm{NH})$ 54.5.19.5, designated by Hill (1983: 172), who provides a detailed discussion of the history relating to the material examined by Tomes.

Type locality: Loyalty Islands.

\section{Diagnosis}

Miniopterus australis differs from $M$. pusillus as described in the above diagnosis of that species.

It differs from $M$. paululus in averaging larger in all external body characters, except ear length and digit 3 phalanx 2 length. For example, forearm length 39.2 (37.4-41.6) 107 v. 37.1 (34.2-38.7) 34 and tibia length 15.9 (14.8-17.3) 107 v. 15.0 (13.9-15.6) 34 . Digit 5 metacarpal length greater relative to ear length (Figure 9a). Skull size very similar to $M$. paululus but averages slightly larger in all measurements except mesopterygoid fossa breadth and $\mathrm{M}^{2}$ length. For example, greatest skull length 14.0 (13.5-18.4) 36 v. $13.8(13.1-14.3) 53$ and $\mathrm{C}^{1} \mathrm{M}^{3}$ length $5.4(5.2-5.6) 36$ v. $5.3(5.1-5.6) 53$. Braincase breadth generally greater relative to upper molar row length (Figure 9b).

It differs from Miniopterus shortridgei in averaging larger in all external body and skull characters. For example, forearm length $39.2(37.4-41.6) 107$ v. 36.8 (33.3-39.3) 148; tibia length 15.9 (14.8-17.3) $107 v$. 15.0 (13.4-16.4) 150; greatest skull length 14.0 (13.514.4) 36 v. $13.3(126 .-13.8) 135$; and $\mathrm{C}^{1} \mathrm{M}^{3}$ length 5.4 (5.2-5.6) 36 v. $5.0(4.6-5.2) 137$.

\section{Miniopterus australis tibialis (Tomes, 1858)}

\section{Vespertilio tibialis Tomes, 1858: 126-127}

Holotype: Stated by Tomes (1858: 126) to be exhibited in the Leyden Museum, where it is supposed to still be located (Tate 1941: 575).

Type locality: Ambon ([ Amboyna) island, Muluku Tenggara, Indonesia.

Specimens examined: Australia; New South Wales Bonalbo Colliery, $28^{\circ} 44^{\prime} \mathrm{S}$; $152^{\circ} 37^{\prime} \mathrm{E}, \mathrm{CM} 877$, ơ, S. Bungawalbin, $29^{\circ} 02^{\prime} S$; $153^{\circ} 17^{\prime} \mathrm{E}$, AM M22797, $\&$, E. Cangai, 29 $30^{\prime}$ '; $152^{\circ} 29^{\prime} \mathrm{E}, \mathrm{AM} \mathrm{M}(10920,12721) 2$ 웅

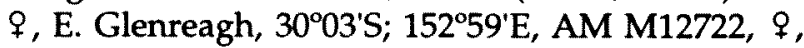
E. Kempsey, $31^{\circ} 05^{\prime} \mathrm{S} ; 152^{\circ} 50^{\prime} \mathrm{E}, \mathrm{CM} 1831-2$, 우, ðै, S. Limeburners, $31^{\circ} 18^{\prime} \mathrm{S}$; $152^{\circ} 57^{\prime} \mathrm{E}$, AM M(21446, 21456, $21465,21476), 3 q q, \delta$, E. Macquarie, 29² $29^{\prime} S$; 
150 07'E, AM M9026-7, \&, o, E. Nimbin Rocks, $28^{\circ} 37^{\prime} \mathrm{S} ; 153^{\circ} 12^{\prime} \mathrm{E}, \mathrm{CM}(10851-3,10857-9), 3$ 와 오, $3 \delta^{\circ} \sigma^{\circ}$. Tooloom, $28^{\circ} 37^{\prime} \mathrm{S} ; 152^{\circ} 25^{\prime} \mathrm{E}, \mathrm{CM}(871,873-6), 3$ 우, 2 ơ ơ. Unknown locality, CM921, $q, \mathrm{E}$.

Queensland - Barretts Lagoon, $18^{\circ} 03^{\prime} \mathrm{S} ; 145^{\circ} 58^{\prime} \mathrm{E}$, QM JM8255, o, E. Blue Lagoon, $22^{\circ} 44^{\prime} 29^{\prime \prime} \mathrm{S}$; 150³8'17"E, CM19095, ð. Bracewell, 23⒌'S; $150^{\circ} 54^{\prime} \mathrm{E}, \mathrm{QM} \mathrm{JM}(436, \mathrm{~S}, 437) 2$ o $\delta$. Bribie Island, 265'S; 15307'E, QLD JM1943E, ठ. Brisbane, Campt Mt, 2724'S; $152^{\circ} 54^{\prime} \mathrm{E}, \mathrm{QM}$ JM (6870E, 6871) ㅇ, 1 Sex Unknown. Buthen Buthen, $13^{\circ} 23^{\prime} \mathrm{S}$; $143^{\circ} 27^{\prime} \mathrm{E}, \mathrm{QM}$ JM $(2450, \mathrm{E}, 2473,2474 \mathrm{E}), 3$ o $\delta$. Cape York, Iron Range $165 \mathrm{kms} \mathrm{NE}$ of Archer River, $12^{\circ} 44^{\prime} \mathrm{S} ; 143^{\circ} 15^{\prime} \mathrm{E}, \mathrm{AM} \mathrm{M}(16084-5$, E) \&, o Cape York, Rocky River, $13^{\circ} 49^{\prime} \mathrm{S} ; 143^{\circ} 28^{\prime} \mathrm{E}, \mathrm{CM} 4487, \mathrm{~S}$, o. Chillagoe, $17^{\circ} 09^{\prime} S ; 144^{\circ} 31^{\prime} \mathrm{E}, \mathrm{CM} 10841$, E, of. Crab Camp, $22^{\circ} 38^{\prime} 45^{\prime \prime} S$; 150 43'46"E, ANWC19073, S, o. Creek on Atherton Rifle Range, $17^{\circ} 16^{\prime} \mathrm{S} ; 145^{\circ} 29^{\prime} \mathrm{E}$, AM M1680, E, $\delta$. Creek South of Coen, $14^{\circ} 06^{\prime} \mathrm{S}$; $143^{\circ} 12^{\prime} \mathrm{E}, \mathrm{AM} \mathrm{M}(16082, \mathrm{E}, 16086-91, \mathrm{E}) 3 \%$ 우 $4 \delta^{\circ} \delta^{\circ}$. Herberton, Extenuate Mine, $17^{\circ} 26^{\prime} \mathrm{S}$; $145^{\circ} 25^{\prime} \mathrm{E}$, QLD $\mathrm{JM}(8420 \mathrm{E}, 8421,8422 \mathrm{E}, 8423,8424 \mathrm{E}, 8425,8426 \mathrm{E}$, 8429 E) 2 \& $q 6 \delta^{\circ} \delta^{\circ}$. Kuranda, $16^{\circ} 49^{\prime}$ S; $145^{\circ} 38^{\prime} \mathrm{E}$, CM(5924, 5925-6 E, 5932 E) 3 우, ㅎ․ Lake Barrine, $17^{\circ} 15^{\prime}$ S; $145^{\circ} 38^{\prime} \mathrm{E}$, Qld JM1450 E, ठ。. Mount Boldy, 4 $\mathrm{km}$ West of Atherton, $17^{\circ} 16^{\prime} \mathrm{S} ; 1^{\circ} 5^{\circ} 29^{\prime} \mathrm{E}, \mathrm{AM} 13610 \mathrm{E}$, ․ Oakleigh Colliery, Glencoe section, $27^{\circ} 39^{\prime} \mathrm{S}$; $152^{\circ} 36^{\prime} \mathrm{E}$, Qld JM416 E, Sex Unknown. Old Irishman Mine, $19^{\circ} 00^{\prime}$ S; $146^{\circ} 17^{\prime} \mathrm{E}$, Qld JM(1675, $1676 \mathrm{E}, 1677$, 1678-1680 E), 6 \& . Ravenswood, $20^{\circ} 06^{\prime} \mathrm{S}$; $146^{\circ} 53^{\prime} \mathrm{E}$, $\mathrm{CM}(15869 \mathrm{E}, 15870-1), 2$ 우 , $\delta$. Rockhampton, $23^{\circ} 23^{\prime} S$; $150^{\circ} 30^{\prime} \mathrm{E}$, Qld JM(6863-6869, 6873-4 E), M(16451 E, 16794 E), 6 ๆ, 3 ठð, 2 Sex Unknown. Rosella Plains, $18^{\circ} 25^{\prime} \mathrm{S} ; 144^{\circ} 28^{\prime} \mathrm{E}$ Qld JM(2940-1 E), $q$, o. Thornton Peak, $16^{\circ} 10^{\prime} \mathrm{S} ; 145^{\circ} 23^{\prime} \mathrm{E}$, AM $\mathrm{M}(13293,13300-5 \mathrm{E}), 3 q \%, 4 \delta \delta$. West Claudie Range, $12^{\circ} 44^{\prime} \mathrm{S} ; 143^{\circ} 17^{\prime} \mathrm{E}$, Qld JM2400, E, $\delta$. Wombah Railway Tunnel, Via Gin Gin, $25^{\circ} 00^{\prime} \mathrm{S}$; 151 ${ }^{\circ} 57^{\prime} \mathrm{E}, \mathrm{CM}(5970,5972-3, \mathrm{E}), 2$ 우 $\sigma^{\circ}$. Wongabel State Forest, $17^{\circ} 19^{\prime} \mathrm{S} ; 1^{\circ} 5^{\circ} 29^{\prime} \mathrm{E}$, AM M16083, E, $\delta$. Locality Unknown, 597 E, ANWC 164525, $q 1$ Sex Unknown.

Papua New Guinea - Putei CM (1990S, 1995E, 1997E, 1998, 1999E, 2000E, 2002, 2010S, 2020S, $2030 \mathrm{E}, 2031 \mathrm{~S}, 2032 \mathrm{E}, 2040,2043 \mathrm{~S}, 2047 \mathrm{E}) 7 q q, 8$ $\delta$ oे.

Seram island, Indonesia: Manusela, $30^{\circ} 10^{\prime} \mathrm{S}$, $129^{\circ} 36^{\prime} \mathrm{E}$, WAM M34722, $\delta$.

\section{Diagnosis}

Miniopterus australis tibialis differs from $M$. australis subsp. indet. from Kai island in that both Australian and New Guinea specimens have a shorter tibia 15.9 (14.8-16.9) 93 and 15.9 (15.2-16.5) 10 , respectively, $v$. $17.1(16.9-17.3) 3$ and a generally shorter forearm length $39.1(37.4-40.8) 93$ and 39.7 (38.8-40.4) 10, respectively, v. 41.1 (40.8-41.6) 3. Most other wing measurements are also smaller (Table 7b). Most skull characters are larger (Table 7a). For example, both the Australian and New Guinea specimens have a longer greatest skull length 14.0 (13.7-14.4) 24 and 14.1 (13.9-14.2) 8, respectively, $v .13 .6(13.5-13.8) 3$.

\section{Distribution}

Queensland, New South Wales (Australia), Papua New Guinea and Seram (this study), Ambon (type locality) and probably Sulawesi, Batchian island, Aru island, Beu island, Mayabit Bay, Waigeo, West Irian (Hill 1983).

\section{Remarks}

Tomes (1858) described Vespertilio tibialis from five specimens, but he noted that it differed little from Miniopterus blepotis except that it is a "trifle smaller, and moreover appears to ... differ remarkably in all the specimens in having the extremity of the tibia perfectly free for nearly a third of its length". He provides measurements for one of these specimens as (in. and lin. converted to $\mathrm{mm}$ ) lengths of: head and body 63.5 ; head 14.8, ear 7.4; tragus 4.2; forearm 39.2-40.2; and tibia 14.8 . Measurements for the other three adult male specimens from the Nicobars are provided in Dobson (1871). Sanborn (1952: 107) considered that the appearance of the extremity of the tibia in the specimen described by Tomes (1858) almost certainly resulted from the interfemoral membrane not being pinned out such that it curls up along the tibia giving the impression of a "slender shank".

\section{Miniopterus australis subsp. indet.}

Three specimens from Desa Elat, Kai island [5 $5^{\circ} 9^{\prime} \mathrm{S}, 1^{\circ} 2^{\circ} 59^{\prime} \mathrm{E}$; WAM M42885 ( $\$$ ); WAM M42724 ( $q$ ) and WAM M42749 ( ()$]$ are distinguished from $M$. australis tibialis as described in the above diagnosis. These specimens are most clearly distinguished by their long tibia (Table 7a, b). They may warrant recognition as a separate subspecies but a larger sample of specimens is required to evaluate their taxonomic status.

\section{Miniopterus paululus Hollister, 1913}

M. paululus Hollister, 1913: 311-312

\section{M. witkampi Sody, 1930: 272-273}

Holotype: United States National Museum No. 105493. Adult in alcohol, skull removed, collected in December 1887, by J.B. Steere.

Type locality: Guimarás islands, Philippines.

\section{Diagnosis}

Miniopterus paululus differs from $M$. pusillus and $M$. australis as described in the above diagnoses for these species. 
Miniopterus paululus differs from $M$. shortridgei in averaging larger in all external body and skull characters except digit 3 phalanx 3 length (see Table $7 \mathrm{a}, \mathrm{b})$. For example, forearm length 37.1 (34.2-38.7) 34 v. 36.8 (33.3-39.3) 148; ear length 10.5 (9.6-11.5) 33 v. $9.7(8.3-10.8) 140$; greatest skull length 13.8 (13.1-14.3) 53 v. $13.3(12.6-13.8) 135$; and $\mathrm{C}^{1} \mathrm{M}^{3}$ length $5.3(5.1-5.6) 53$ v. 5.0 (4.6-5.2) 137. Ear length generally longer relative to digit 5 metacarpal length (Figure 9a); and upper molar cusp row generally longer relative to braincase breadth (Figure 9b).

\section{Remarks}

Revilliod (1914) diagnosed $M$. australis from $M$. pusillus macrocneme by its tragus which he stated projects anteriorly at its distal end with an almost horizontal, irregular dentate cranial margin; whereas in macrocneme the tragus does not project strongly forward and there is no clear dentate cranial margin. We found no such strong anterior margin in the M. australis available to us. Hill (1983) stated that specimens of australis from more western localities do not have a tragus with this dentate margin.

\section{Miniopterus paululus paululus Hollister, 1913}

Holotype and Type locality: described above.

Specimens examined: Philippine islands - Leyte island, $10^{\circ} 28^{\prime} \mathrm{S}, 124^{\circ} 45^{\prime} \mathrm{E}$, WAM M29040 E, ?. Majuyod, $9^{\circ} 43^{\prime} \mathrm{S}$, $123^{\circ} 10^{\prime} E$, WAM M25874-5, 2 $q$. Negros island, $9^{\circ} 20^{\prime} \mathrm{N}, 123^{\circ} 18^{\prime} \mathrm{E}$, WAM M29041-3, 3 ㅇ․

\section{Diagnosis}

Miniopterus p. paululus differs from M. p. witkampi in averaging slightly larger in most wing measurements (Table $7 \mathrm{~b}$ ). For example, forearm length $37.0(35.8-37.9) 6$ v. $36.3(34.2-37.1) 6$ and digit 5 metacarpal length $29.6(28.4-30.4) 6$ v. 29.0 (27.3-29.8) 6. Digit 3 phalanx 3 length generally longer relative to ear length (Figure 11a). It differs in that all skull characters, except palatal length and $\mathrm{M}^{2}$ breadth, average smaller (Table 7a). For example, greatest skull length $13.7(13.5-13.8) 5 v$. 13.9 (13.5-14.3) 5 and braincase breadth $7.0(6.8$ 7.1) 5 v. $7.2(7.2-7.3) 5$. Braincase breadth narrower relative to $\mathrm{I}_{1} \mathrm{M}_{3}$ length (Figure $11 \mathrm{~b}$ ).

Miniopterus p. paululus differs from M. p. graysonae subsp. nov. in averaging slightly smaller in most external body and skull characters, except tail to vent length, digit 3 phalanx 2 length and zygomatic width (Table $7 \mathrm{a}, \mathrm{b}$ ). For example, forearm length $37.0(35.8-37.9) 6$ v. $37.4(36.5-38.7) 22$; tibia length 14.8 (14.2-15.4) 6 v. 15.2 (14.4-15.6) 22; and greatest skull length $13.7(13.5-13.8) 5$ v. $13.8(13.1-14.3) 43$. Ear generally longer relative to digit 3 phalanx 3 length (Figure 11a).

\section{Distribution}

Majuyod and Negros island (this study), Guimarás island (type locality), Philippines.
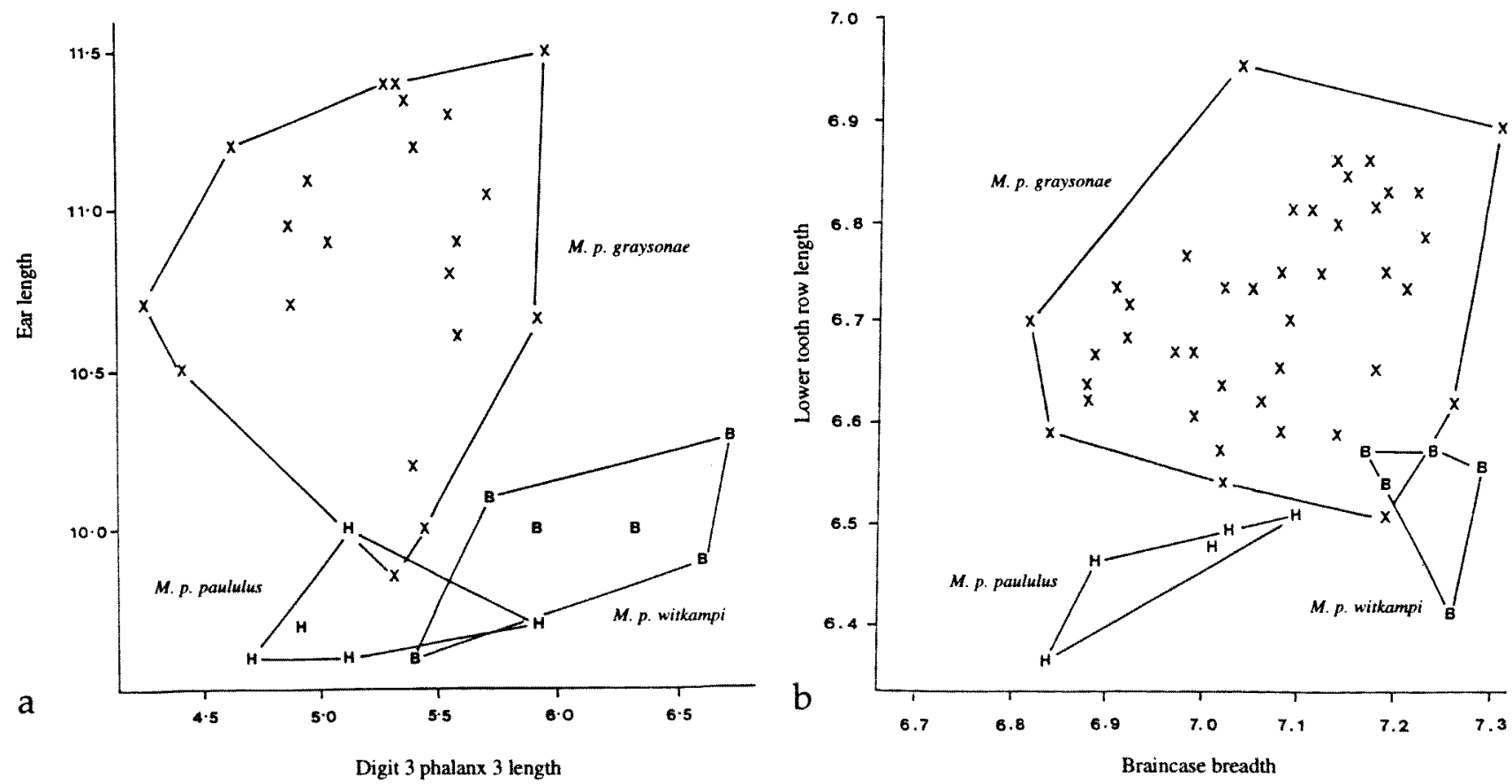

Figure 11 Plot of (a) ear length $(\mathrm{mm})$ versus digit 3 phalanx 3 length $(\mathrm{mm})$ and $(\mathrm{b})$ lower tooth row length ( $\mathrm{mm})$ versus braincase breadth for island populations of adult Miniopterus paululus paululus, M. p. witkampi and M. $p$. graysonae subsp. nov. Island codes as for Figure 2. 


\section{Remarks}

The forearm length of the type specimen of $M . p$. paululus fall within the range of our measurements of this taxon, but the measurements of the digit 3-5 metacarpal length and most of the skull measurements of the type, except $\mathrm{I}_{1} \mathrm{M}_{3}$ are smaller than those presented herein (see Hollister 1913).

\section{Miniopterus paululus witkampi Sody, 1930}

\section{M. witkampi Sody, 1930: 272-273}

Holotype: The Sody Collection. Ex. Muzeum Zoologicum Bogoriensis No. 422, adult male, collected 24 January 1928.

Type locality: Lobang Ipoe, Koetai, East Kalimantan, Borneo island.

Specimens examined: Borneo Island- Gomantong, Sabah, 5'31' N, $118^{\circ} 04^{\prime} \mathrm{E}$, WAM M (26002-6, 26007 E) 3 우, 3 o $\delta^{\circ}$.

\section{Diagnosis}

Miniopterus p. witkampi differs from M. p. paululus as described in the above diagnosis.

It differs from $M$. paululus graysonae in averaging smaller in all external body characters, except digit 3 phalanx 3 length (Table $7 \mathrm{~b}$ ). For example, forearm length $36.3(34.2-37.1) 6$ v. $37.4(36.5-38.7) 22$ and tibia length $14.7(13.9-15.2) 6$ v. $15.2(14.4-15.6) 22$. Ear length shorter relative to digit 3 phalanx 3 length (Figure 11a). It averages slightly larger in measurement of overall skull size, such as greatest skull length, zygomatic width, braincase breadth and $\mathrm{M}^{3} \mathrm{M}^{3}$ distance and slightly smaller in other skull measurements such as mastoid width cranial skull height and $\mathrm{C}^{1} \mathrm{M}^{3}$ length (Table 7a). $\mathrm{I}_{1} \mathrm{M}_{3}$ length generally shorter relative to braincase breadth (Figure 11b).

\section{Distribution}

Koetai, East Kalimantan (type locality), and Gomantong, East Sabah, Borneo island.

\section{Miniopterus paululus graysonae subsp. nov., Kitchener}

Holotype: Western Australian Museum No. M44339, adult male, weight $5.8 \mathrm{gm}$, collected by Ir Ibnu Maryanto (Museum Zoologicum Bogoriense) and Mr Ronald Johnstone (Western Australian Museum) on 28 April 1993.

Type locality: Bangruti Cave, near Adaut, Selaru island, Tanimbar Islands Group, Maluku Tenggara, Indonesia, (ca. $8^{\circ} 09^{\prime} \mathrm{S}, 131^{\circ} 08^{\prime} \mathrm{E}$ ), at sea level.

Paratypes: Selaru Island - Adaut, $8^{\circ} 09^{\prime} \mathrm{S}, 131^{\circ} 08^{\prime} \mathrm{E}$, WAM M(44319-20, 44322-4, 44325E, 44326, 44327S, 44328-9, 44330S, 44331-3, 44335E, 44336, 44338, 44340-44 S, 44346-7S, 44348E, 44350, 44351S, 44353S,
44354, 44355-7S, 44358, 44359-61S, 44362, 44363S, $44366,44367 \mathrm{~S}, 44369 \mathrm{E}, 44371,44372-4 \mathrm{~S}, 44377 \mathrm{~S}) 20$ 우, $24 \delta \delta$.

\section{Diagnosis}

Miniopterus paululus graysonae differs from $M . p$. paululus and M. p. witkampi as described in the above diagnoses of these subspecies.

\section{Distribution}

Known only from Selaru island, Tanimbar Island Group.

\section{Etymology}

Named after Ms Jacky Grayson, who contributed greatly to this paper by removing skulls and recording external body measurements.

\section{Miniopterus shortridgei Laurie \& Hill, 1957}

Miniopterus australis shortridgei Laurie and Hill, 1957: 128 (renamed)

M. australis minor Laurie and Hill 1954: 72-73

Holotype: British Museum of Natural History No. BM 9.1.5.426 (Collector's no. 1451); adult male; skin (in alcohol) and skull separate; collected by G.C. Shortridge on 3 March 1908.

Type locality: Kalipoetjang, Tji - Tandoei River, south Java.

Specimens examined: Java island - Kiskenda, $7^{\circ} 06^{\prime} \mathrm{S}$ $110^{\circ} 16^{\prime} \mathrm{E}$, WAM M(39334E, 39353E) $+\%$. Sukabumi, $7^{\circ} 15^{\prime} S, 106^{\circ} 50^{\prime} \mathrm{E}$, WAM M(30007, 3000101), $q 2$ o $\delta$ Madura island - Sampang, $7^{\circ} 13^{\prime} S$, $113^{\circ} 15^{\prime} \mathrm{E}$, WAM M39411, $\varnothing^{\circ}$. Lombok island Bang Kang, $8^{\circ} 30^{\prime} \mathrm{S}, 116^{\circ} 10^{\prime} \mathrm{E}$, WAM M(35855, 35860$1,35863-4,35865 \mathrm{E}, 35866-8,35870,35959 \mathrm{E}, 35961) 8$ $\uparrow q, 2 \delta \delta$. Sumbawa island - Batu Dulang, $8^{\circ} 35^{\prime} \mathrm{S}$, $117^{\circ} 18$ 'E, WAM M (31769-72, 31773S, 31774, 31776$81,31782 \mathrm{~S}, 31783-4,31787-5,31796 \mathrm{E}, 31797,31798 \mathrm{E}$, $31800-8,31812,31813 \mathrm{E}, 31814-6,31818,31853 \mathrm{E}$ 31854-5) $14 ㅇ ㅇ, 31$ 워 Desa Sangeang, $8^{\circ} 18^{\prime} \mathrm{S}$, $118^{\circ} 56^{\prime} \mathrm{E}$, WAM M31556 $\sigma^{\circ}$. Moyo island - Sebotok, $8^{\circ} 09^{\prime} 30^{\prime \prime} \mathrm{S}, 117^{\circ} 37^{\prime} 15^{\prime \prime}$ E, WAM M31906, 9 . Tangung Pasir, 8²3'15" S, 117 31'30" E, WAM M31960, \&. Alor island - Kalabahi, $8^{\circ} 14^{\prime} \mathrm{S}, 124^{\circ} 32^{\prime} \mathrm{E}$, WAM $\mathrm{M}(37518-21,37543$, 37564, 37565E, 37566, 37625, 37627) 4 q $q, 6$ o $\delta^{\circ}$. Roti island - Baa, $10^{\circ} 44^{\prime} \mathrm{s}$, $123^{\circ} 06^{\prime} \mathrm{E}$, WAM M(35358, 35388) $\$$, ðOeseli, $10^{\circ} 51^{\prime} \mathrm{S}, 123^{\circ} 05^{\prime} \mathrm{E}, \mathrm{WAM} \mathrm{M}(35498,35500-2) 3$ 우, ठ. Savu island - Menia, $10^{\circ} 29^{\prime} \mathrm{S}, 121^{\circ} 55^{\prime} \mathrm{E}$, WAM $\mathrm{M}(35114,35126,35128,35139,35140 \mathrm{~S}, 35141-2$, $35143 \mathrm{~S}, 35144-6,35147 \mathrm{E}, 35148-51,35152 \mathrm{~S}, 35153$, $35154-5,35165-6,35168-70,35171 \mathrm{E}, 35172,35173 \mathrm{E}$, $35175-6,35178-9,35218-20,35221 \mathrm{E}, 35223-6,35228-$ $30,35231 \mathrm{E}, 35232-3,35234 \mathrm{E}, 35235-9,35240 \mathrm{E}, 35241-$ $3,35245 \mathrm{E}, 35246-54,35255 \mathrm{E}, 38$ q 9,30 ठे ठे. Timor island - Lifuleo Oisina, $9^{\circ} 18^{\prime} \mathrm{S}, 123^{\circ} 30^{\prime} \mathrm{E}$, WAM M38065, \&. Semau island - Desa Uiasa, $10^{\circ} 10^{\prime} \mathrm{S}$, 
1232'ㄹ, WAM M(33066E, 33067-8, 33069-71 E), 3 $q, 3$ of $\delta$ Wetar island - Desa Ipokil, $7^{\circ} 50^{\prime} S$, $126^{\circ} 16^{\prime} \mathrm{E}$, WAM M44528, q. Selaru island - Adaut, $8^{\circ} 09^{\prime} \mathrm{S}, 131^{\circ} 08^{\prime} \mathrm{E}$,WAM M44334 S, $\delta^{\circ}$.

\section{Diagnosis}

Miniopterus shortridgei differs from M. pusillus, $M$. australis and $M$. paululus as described in the above diagnoses of these species.

\section{Distribution}

Java, Madura, Lombok, Sumbawa, Moyo, Alor, Wetar, Selaru (Tanimbar Islands), Timor, Semau, Roti and Savu islands, Indonesia.

\section{Remarks}

Laurie and Hill (1954: 72) stated that in the type series of $M$. shortridgei the wing membrane is inserted at the end of the tibia near the heel, and that the os calcis with the tail membrane also starts at that point. This was also the case in the specimens we examined from throughout the range of this species. Laurie and Hill (1954: 73) list measurements for the holotype and five paratypes of $M$. shortridgei. They state that the skull is very similar to $M$. a. australis but definitely shorter and that the 16 specimens examined by them had a skull length of 12.8-13.3, $\mathrm{C}^{1} \mathrm{M}^{3}$ length 4.8-5.0 and $\mathrm{C}^{1} \mathrm{C}^{1}$ breadth 3.2-3.6. Specimens we studied were similar in size, except that $\mathrm{C}^{1} \mathrm{C}^{1}$ breadth tends to be larger in our sample. Goodwin (1979: 120) provided measurements for a Miniopterus from Timor island which he attributed to M. a. australis, but stated that it was "close to M. a. shortridgei of Java but averages slightly larger in forearm and certain other measurements". We consider the Timor specimens examined by Goodwin (1979) to be $M$. shortridgei.

However, our DFA and univariate analyses indicated that the Timor specimens differed morphologically somewhat from the nominate form on Java. The specimens from Timor island were grouped, along with those from Savu, Roti, Semau, Wetar and Selaru islands, into an Outer Banda Arc form (the geological origins of Wetar are unclear, see General Discussion); while those from the inner (volcanic) Banda Arc islands of Alor, Moyo, Sumbawa, Lombok, Madura and Java comprised an inner Banda Arc form. This latter form averaged larger in all cranial, dentary and dental characters, except cranial height (Table 7a) and most external body measurements, except tail to vent length, ear length and digit 3 phalanx 3 length (Table $7 b$ ). The Inner Banda Arc form also generally had a longer dentary relative to intercochlear distance (Figure 12a) and a generally longer digit 3 phalanx 2 length relative to digit 3 phalanx 1 length (Figure 12b).

\section{GENERAL DISCUSSION}

The four species of Miniopterus studied (pusillus, australis, paululus and shortridgei) showed considerable geographic variation in intraspecific morphology for cranial, dentary, dental (except $M$. pusillus) and external body characters. In the case of
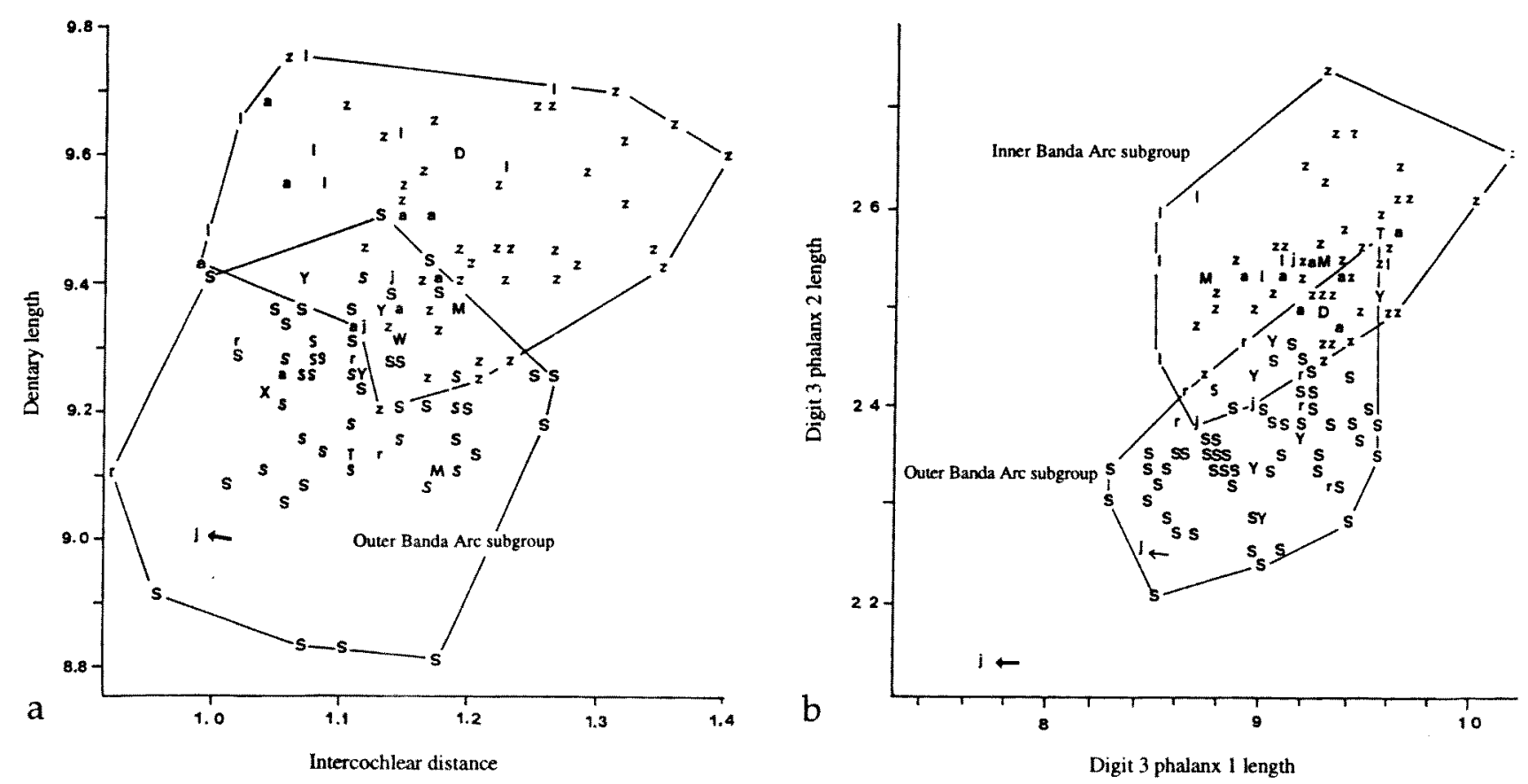

Figure 12 Plot of (a) dentary length ( $\mathrm{mm}$ ) versus intercochlear distance (mm) and (b) digit 3 phalanx 2 length (mm) versus digit 3 phalanx 1 length $(\mathrm{mm})$ for island populations of adult Miniopterus shortridgei for the two population subgroupings (Inner and Outer Banda Arc/Wetar island). Island codes as for Figure 2. 
the former three species, their intraspecific morphology diverged sufficiently to warrant subspecific status. In the remaining species, $M$. shortridgei, two reasonably distinct forms are recognised. One of these forms is restricted to Java and the volcanic islands of the Inner Banda Arc, which are a volcanic extension of Western Sumatra and Java (Michaux 1991); the other occurs on the gondwanic islands of the Outer Banda Arc, and apparently also on Wetar island. The single specimen from Wetar island is a damaged skull only. A DFA run with a reduced set of variables, so as to include this Wetar island specimen in the analysis as an unallocated specimen, placed it with specimens from the Outer Banda Arc group of islands.

Intraspecific morphological variation in both $M$. pusillus and $M$. shortridgei appeared to be most marked in the general region of Alor and Wetar islands. Interestingly, Alor and Wetar islands, like Roma and Kambing islands, now inactive volcanically, are characterised by reef-limestone terraces uplifted to $500-800 \mathrm{~m}$ above sea level (see Hamilton 1979). Perhaps the more recent volcanic activity on Inner Banda Arc islands to the west of Alor island not only impacted on the habitat and faunal assemblages on those islands, but may in some way have favoured the development of a particular bat ecomorph.

The western $M$. p. pusillus (Java-Sumbawa) is larger in all characters than the eastern form, $M$. pusillus subsp. indet. A (Alor and Roti). Further, the Inner Banda Arc form of $M$. shortridgei (Java-Alor) is larger for most characters than the form on the Outer Banda Arc and Wetar island. The region of this differentiation reflects a pattern documented by Kitchener and Suyanto (1996), Kitchener, Konishi and Suyanto (1996) and Kitchener, Packer and Maryanto (1996) who examined intraspecific morphological variation in ten species of bat and a mouse in the region of southern Indonesia between Java and the Kai islands. They noted that morphological differentiation tended to occur in the eastern parts of the distributional range of the species examined, or in the Outer Banda Arc on the islands of Sumba, Roti, Savu, Semau and Timor. The exceptions to this were two species that morphologically diverged in the western part of this region. These were Scotophilus collinus Sody, 1936, which had two forms that diverged between Bali and Lombok islands, and Hipposideros diadema (Geoffroy, 1813), which had two subspecies that interfaced between Lombok and Sumbawa islands.

The trend for $M$. pusillus and $M$. shortridgei to become smaller in overall size on the eastern and southern islands in the Lesser Sundas is also observed in seven of the ten bat species referred to above. The exceptions were Cynopterus nusatenggara Kitchener and Maharadatunkamsi, 1991 and
Hipposideros sumbae Oei, 1960, which increase in size, and Scotophilus collinus Sody, 1936 which shows no clear such trends in morphology. Kitchener and Suyanto (1996) stated that this trend for overall skull and body dimensions to change with longitude, at least for the most eastern islands of Tanimbar and Kai, which have a less severe climate, may in part be influenced by Bergmann's effect. However, within the Lesser Sundas a complex interplay of factors is likely to be involved. This is indicated by the study by Kitchener and Maharadatunkamsi (1996) on Cynopterus nusatenggara which showed that most cranial, dentary and external body measurements became larger to the east or on the more isolated islands, and smaller on the islands to the south. However, the cranium and teeth also were smaller on the larger (irregularly shaped) islands.

The two forms of $M$. shortridgei overlap somewhat morphologically, but not particularly so in the region where the islands in the gondwanic outer Banda Arc and volcanic inner Banda Arc are closest. This is between Alor and Timor (the placement of Wetar island in these island Arcs is not clear). For example, a few specimens from the more western islands of Java, Moyo and Sumbawa were misclassified to the Outer Banda Arc form. For this reason, these two forms are not recognised as subspecies. It may well be that examination of further specimens from the region of the interface between these forms (Alor, Timor and Wetar islands) may provide a stronger case for the recognition of them as subspecies.

While the systematic groupings of forms in this paper into species differs somewhat from that of Hill (1983), we place the forms we studied into similar subspecies taxa. We are also doubtful that the eastern Indonesian form of Miniopterus pusillus on Timor and asociated islands and on Seram (and Ambon) represent the form macrocneme. However, we recognised that other taxonomic tools need to be applied to further resolve the taxonomy of this group. Our experience with this genus leads us to agree with Goodwin (1979) that resolution of the taxonomy of many forms of Miniopterus is exceedingly difficult because morphological differences between even sympatric species are sometimes minor and that pelage colour is of little taxonomic value.

\section{ACKNOWLEDGEMENTS}

We gratefully acknowledge the support of the Director, Western Australian Museum, Mr Andrew Reeves; the Director, Puslitbang Biologi (LIPI), Dr Soetikno Wirjoatmodjo, and the Director, Balitbang Zoologi (LIPI), Drs M. Amir.

To our many colleagues who assisted greatly in the field, particularly Dr R.A. How and Mr R. 
Johnstone, Western Australian Museum; Ir I. Maryanto, Ir Maharadatunkamsi and Bapak Boeadi, Balitbang Zoologi, we extend our thanks for their efforts and companionship.

Particular thanks to Mrs Jacky Grayson, who removed most skulls and measured the external body characters; Mr Tim Morrison, who measured all the skulls entered the data and undertook the preliminary analyses for outlier values; and Mrs N. Cooper, Western Australian Museum who ran the statistical analyses.

Dr R.A. How kindly commented on the final manuscript.

Thanks also to Mr Steven Dyck, Queensland Museum; Mr John Womby, CSIRO; and Miss Linda Gibson, Australian Museum for the loan of specimens.

Expedition costs were defrayed by grants to $D$. Kitchener from: National Geographic Society, Washington, Scott Trust, Sydney and the Australian Nature Conservation Agency, Canberra. Garuda Indonesia kindly defrayed freight costs of the expeditions. Mrs A. Nevin, Western Australian Museum, typed the manuscript.

\section{REFERENCES}

Audley-Charles, M.G. (1987). Dispersal of Gondwanaland: relevance to evolution of the angiosperms. In Biogeographical evolution of the Malay Archipelago (Ed. T.C. Whitmore). pp 5-25. (Oxford Monographs on Biogeography. Clarendon Press, Oxford).

Corbet, G.B. and Hill, J.E. (1992). The mammals of the Indomalayan Region (Natural History Museum Publ. Oxford Univ. Press, Oxford).

Dobson, G.E. (1871). Description of four new species of Malayan bats, from the collection of Dr Stoliczka. J. Asiatic Soc. Bengal. 40: 260-267.

Dobson, G.E. (1876). Monograph of the Asiatic Chiroptera and catalogue of the species of bats in the collection of the Indian Museum (Calcutta, London).

Ellerman, J.R. and Morrison-Scott, T.C.S. (1951). Checklist of Palaearctic and Indian mammals 1758-1946 (London).

Goodwin, R.E. (1979). The bats of Timor: systematics and ecology. Bull. Am. Mus. nat. Hist. 163: 73-122.

Hamilton, W. (1979). Tectonics of the Indonesian region. Geol. Surv. Prof. Pap. 1078: 1-345.

Hill, J.E. (1971). Bats from the Solomon Islands J. nat. Hist. 5: 573-581.

Hill, J.E. (1983). Bats (Mammalia: Chiroptera) from IndoAustralia. Bull. Br. Mus. nat. Hist. (Zool.). 45: 103-208.

Hill, J.E. (1991). Bats (Mammalia: Chiroptera) from the Togian islands, Sulawesi, Indonesia. Bull. Am. Mus. nat. Hist. 206: 168-175.

Hollister, N. (1913). A review of the Philippine land mammals in the United States National Museum. Proc. U.S. nat. Mus. 46: 299-341.

Kitchener, D.J. and Suyanto, A. (1996). Intraspecific morphological variation among island populations of small mammals in southern Indonesia. pp. 7-13. In D.J. Kitchener and A. Suyanto (eds), Proceedings of the first international conference on eastern IndonesianAustralian vertebrate fauna, Manado, Indonesia, November 22-26, 1994 (Western Australian Museum, Perth).

Kitchener, D.J., Hisheh, S., Schmitt, L.H. and Maharadatunkamsi (1997). Morphological and genetic variation among island populations of Dobsonia peronii (Chiroptera, Pteropodidae) from the Lesser Sunda Islands, Indonesia. Trop. Biod. 4:35-51.

Kitchener, D. J.' Konishi, Y. and Suyanto, A. (1996). Morphological variation among Eastern Indonesian island populations of Hipposideros biclor (Chiroptera: Hipposideridae), with descriptions of three new subspecies. Rec. West. Aust. Mus. 18:179192.

Kitchener, D. J. and Maharadatunkamsi (1996). Geographic variation in morphology of Cynopterus nusatenggara (Chiroptera, Pteropodidiae) in southeastern Indonesia, and description of two new subspecies. Mammalia 60:255-276.

Kitchener, D.J., Packer, W.C. and Maryanto, I. (1996). Morphological variation among populations of Scotophilus kuhlii (sensu lato) Leach, 1821 (Chiroptera: Vespertilionidae) from the Greater and Lesser Sunda Islands, Indonesia. Trop. Biod. (in press).

Koopman, K. (1982). Results of the Archbold Collections No. 109. Bats from eastern Papua and the east Papuan islands. Am. Mus. Novit. 2747: 1-34.

Laurie, E.M.O. and Hill, J.E. (1954). List of land mammals of New Guinea, Celebes and adjacent islands 1758-1952 (London).

Laurie, E.M.O. and Hill, J.E. (1957). Renaming of Miniopterus australis minor Laurie and Hill. J. Mammal. 38: 128.

McCabe, R. and Cole, J. (1989). Speculations on the late Mesozoic and Cenozoic evolution of the Southeast Asian margin. pp. 143-160 In (ed.) Z. Beu-Avraham) The evolution of the Pacific Ocean Margins. Oxford Monographs in Geology and Geophysics. Volume 8 (Oxord University Press, New York).

Maeda, K. (1982). Studies on the classification of Miniopterus in Eurasia, Australia and Melanesia. Honyurui Kagaku (Mammalian Science) Suppl. No. 1: 1-176.

Michaux, B. (1991). Distributional patterns and tectonic development in Indonesia: Wallace reinterpreted. In (eds) P.Y. Ladiges, C.J. Humphries and L.W. Martinelli pp 25-36 Austral biogeography (CSIRO Australia, Melbourne).

Norusis, M.J. (1986). Advanced statistics. SPSS/PC+ for the IBM PC/XT/AT (SPSS inc, Chicago, Illinois).

Petersen, R.L. (1981a). The systematic status of Miniopterus australis and related forms. Bat. Res. News 22: 48 .

Petersen, R.L. (1981b). Systematic variation in the tristis group of the bent-winged bats of the genus Miniopterus (Chiroptera: Vestertilionidae). Canad. J. Zool. 59: 828-843.

Revilliod, P. (1914). Les mammiferes de la NouvelleCalédonie et des îles Loyalty. Nova Caledonia 1: 341365. 
Sanborn, C.C. (1952). Philippine Zoological Expedition 1946-1947. Mammals. Field. Zool. 33: 89-158.

Sody, H.J.V. (1930). On some new or insufficiently known mammals from Java, Borneo and Celebes. Natuurk. Tijdschr. Ned. -Ind. 90: 258-273.

Tate, G.H.H. (1941). Results of the Archbold Expeditions. No. 40. Notes on vespertilionid bats. Bull. Am. Mus. nat. Hist. 78: 567-597.
Tomes, R.F. (1858). A monograph of the genus Miniopterus. Proc. Zool. Soc. Lond. 115-128.

Wroughton, R.C. (1918). Summary of the results from the Indian mammal survey of the Bombay Natural History Society Part II. J. Bombay nat. Hist. Soc. 26: 1958.

Manuscript received 11 November 1996; accepted 15 August 2001. 